\title{
Article \\ Study of ALDH from Thermus thermophilus-Expression, Purification and Characterisation of the Non-Substrate Specific, Thermophilic Enzyme Displaying both Dehydrogenase and Esterase Activity
}

\author{
Kim Shortall $^{1}\left(\mathbb{D}\right.$, Edel Durack ${ }^{2}$, Edmond Magner ${ }^{1}$ Ed $^{(}$and Tewfik Soulimane $^{1, *}$ \\ 1 Department of Chemical Sciences, Bernal Institute, University of Limerick, V94 T9PX Limerick, Ireland; \\ kimleah.shortall@ul.ie (K.S.); edmond.magner@ul.ie (E.M.) \\ 2 Department of Biological Sciences, University of Limerick, V94 T9PX Limerick, Ireland; edel.durack@ul.ie \\ * Correspondence: Tewfik.Soulimane@ul.ie; Tel.: +353-86-123-8746
}

check for updates

Citation: Shortall, K.; Durack, E.; Magner, E.; Soulimane, T. Study of ALDH from Thermus thermophilus-Expression, Purification and Characterisation of the Non-Substrate Specific,

Thermophilic Enzyme Displaying both Dehydrogenase and Esterase Activity. Cells 2021, 10, 3535.

https://doi.org/

10.3390/cells10123535

Academic Editors: Silvia Garavaglia and Concettina La Motta

Received: 12 November 2021 Accepted: 11 December 2021 Published: 14 December 2021

Publisher's Note: MDPI stays neutral with regard to jurisdictional claims in published maps and institutional affiliations.

Copyright: (c) 2021 by the authors. Licensee MDPI, Basel, Switzerland. This article is an open access article distributed under the terms and conditions of the Creative Commons Attribution (CC BY) license (https:// creativecommons.org/licenses/by/ $4.0 /)$.

\begin{abstract}
Aldehyde dehydrogenases (ALDH), found in all kingdoms of life, form a superfamily of enzymes that primarily catalyse the oxidation of aldehydes to form carboxylic acid products, while utilising the cofactor $\mathrm{NAD}(\mathrm{P})^{+}$. Some superfamily members can also act as esterases using $p$-nitrophenyl esters as substrates. The $\mathrm{ALDH}_{\mathrm{Tt}}$ from Thermus thermophilus was recombinantly expressed in E. coli and purified to obtain high yields (approximately 15-20 mg/L) and purity utilising an efficient heat treatment step coupled with IMAC and gel filtration chromatography. The use of the heat treatment step proved critical, in its absence decreased yield of $40 \%$ was observed. Characterisation of the thermophilic $\mathrm{ALDH}_{\mathrm{Tt}}$ led to optimum enzymatic working conditions of $50{ }^{\circ} \mathrm{C}$, and a $\mathrm{pH}$ of $8 . \mathrm{ALDH}_{\mathrm{Tt}}$ possesses dual enzymatic activity, with the ability to act as a dehydrogenase and an esterase. $\mathrm{ALDH}_{\mathrm{Tt}}$ possesses broad substrate specificity, displaying activity for a range of aldehydes, most notably hexanal and the synthetic dialdehyde, terephthalaldehyde. Interestingly, para-substituted benzaldehydes could be processed efficiently, but ortho-substitution resulted in no catalytic activity. Similarly, $\mathrm{ALDH}_{\mathrm{Tt}}$ displayed activity for two different esterase substrates, $p$-nitrophenyl acetate and $p$-nitrophenyl butyrate, but with activities of $22.9 \%$ and $8.9 \%$, respectively, compared to the activity towards hexanal.
\end{abstract}

Keywords: aldehyde dehydrogenase; heat treatment purification; substrate specificity; esterase activity; biochemical characterisation; thermophilic enzyme

\section{Introduction}

Found in all kingdoms of life, aldehyde dehydrogenases (ALDH) (EC;1.2.1.3) constitute a large family of $\mathrm{NAD}(\mathrm{P})^{+}$-dependent enzymes with a molecular mass of ca. $50-60 \mathrm{kDa}$, and are composed of 450-500 amino acids. ALDHs exist as dimers [1], tetramers [2-4] and hexamers [5]; however, the latter are less prevalent, with only two resolved structures available to date [6-8]. Their structures consist of three conserved domains, the catalytic domain, the cofactor binding domain, and the oligomerisation domain [1], which work together to catalyse the conversion of an aldehyde substrate using $\mathrm{NAD}(\mathrm{P})^{+}$cofactor to form the corresponding carboxylic acid and $\mathrm{NAD}(\mathrm{P}) \mathrm{H}$. Additionally, some ALDHs can act as esterases [9,10] or can reduce nitrate [11], indicating that this family of enzymes possess broad catalytic properties. There is evidence that dehydrogenase and esterase activity of ALDH occurs within the same active site, utilising the same catalytic residues [12,13]. The dehydrogenase activity of ALDH occurs in five distinct steps [13] (demonstrated with human numbering): (1) activation of the catalytic thiol, Cys302, using a water molecule for water-mediated deprotonation by Glu268; (2) consequential nucleophilic attack on the electrophilic aldehyde by the thiol group of the catalytic cysteine; (3) 
formation of a tetrahedral thiohemiacetal intermediate, via deacylation, coupled with concomitant hydride transfer to the pyridine ring of $\operatorname{NAD}(\mathrm{P})^{+} ;(4)$ hydrolysis of the resulting thioester; and (5) dissociation of the reduced cofactor with concomitant regeneration of the enzyme via $\mathrm{NAD}(\mathrm{P})^{+}$binding [13]. Esterase activity also includes five steps utilising the same catalytic residues: (1) Cys302 is activated by hydrogen abstraction from Glu268; (2) thiolate ion attacks the $p$-nitrophenyl ester substrate creating an oxyanion intermediate; (3) the intermediate rearranges and the nitrophenol group leaves; (4) Glu268 abstracts hydrogen from an ordered water molecule making it a nucleophile and attacks the carbonyl in the thioacyl enzyme complex; and (5) formation of the tetrahedral intermediate and release of the carboxylic acid and free enzyme [13].

ALDH enzymes catalyse the conversion of an aldehyde to carboxylic acid with the requirement of cofactor, whereas hydrolysis of an ester can be achieved by ALDH without $\mathrm{NAD}(\mathrm{P})^{+}$(Scheme 1). Previous studies highlight that the addition of a cofactor can enhance or inhibit esterase activity without being directly involved in the catalytic process $[9,14,15]$. Human ALDH1 and 2 isozyme's esterase activity is accelerated with addition of cofactor, while the activity of ALDH3 is inhibited [15].

(a)

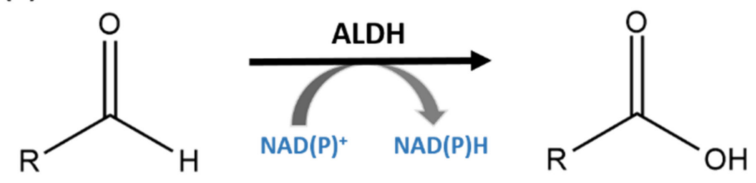

(b)

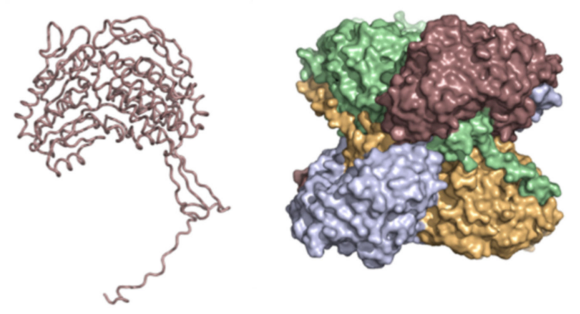

Scheme 1. ALDH reaction mechanism highlighting $\mathrm{ALDH}_{\mathrm{Tt}}$ monomeric and tetrameric structure (PDB ID: 6FJX) (a) dehydrogenase activity using cofactor, (b) esterase activity [14].

ALDHs are often not substrate specific, and can oxidise a wide range of aliphatic and aromatic, endogenous and exogenous aldehydes [16-18], which might be related to their broad spectrum of associated biological functions [5]. The primary function of ALDHs is their role in detoxification mechanisms [19-21], while other functions include biosynthesis [22,23] and non-enzymatic roles, such as antioxidant [24,25], structural [26], and regulatory function $[27,28]$.

While ALDHs have been well-characterised in humans, emerging research places a primary focus on their prokaryotic counterpart's structure and function, which has been less explored until recently [29-31]. The scope of prokaryotic ALDH function spans much wider than eukaryotes $[5,19,31,32]$. For example, the E. coli enzymes phenylacetaldehyde dehydrogenase and lactaldehyde dehydrogenase were characterised after the ALDH1, 2 , and 3 from humans $[1,2,33]$, and are involved in the specific metabolic pathways of phenylalanine and fucose respectively. Other examples include a long-chain alkane degrading ALDH from the thermophilic Geobacillus thermoleovorans $\left(\mathrm{ALDH}_{\mathrm{Gtv}}\right)$ and betaine biosynthesis in E. coli [34,35]. Recently, characterisation of prokaryotic ALDHs has led to understanding of niche features and characteristics within the superfamily, such as extensions consisting of non-functional domains [29]. Interestingly, in the last decade, 
the presence of retinoic acid within prokaryotes was discovered [36,37], highlighting the possibility of retinoid signalling pathways dependent on ALDH and cytochrome oxidases for the conversion of retinaldehyde to retinoic acid. These mechanisms, until recently, were thought to be only of animal origin, but emerging research suggests the contrary [36].

Many ALDHs possess broad substrate specificity, and, in some cases, the true biological substrate(s) has not been identified. Human ALDH1 family members are primarily characterised as retinaldehyde oxidising isozymes. A recent study demonstrated that ALDH1A members could process medium chain aliphatic compounds as well as retinaldehyde [22]. The ALDH from Geotrichum candidum $\left(\mathrm{ALDH}_{\mathrm{Gc}}\right)$ displayed catalytic activity with an extensive range of aldehyde substrates [16]. $\mathrm{ALDH}_{\mathrm{Gc}}$ demonstrated conserved or increased specific activity for a spectrum of para-substituted benzaldehydes, short to medium chain aliphatics (acetaldehyde to heptanal), and dialdehydes, including terephthalaldehyde with respect to benzaldehyde. Thermophilic ALDHs have also proven to have broad substrate specificity. $\mathrm{ALDH}_{\mathrm{Gtv}}$ can process medium to long chain aldehydes, while ALDH from Geobacillus thermodenitrificans $\left(\mathrm{ALDH}_{\mathrm{Gtd}}\right)$ and Pseudomonas putida $\left(\mathrm{ALDH}_{\mathrm{Pp}}\right)$ exhibited activity for 15 and 21 different aromatic and aliphatic substrates respectively, working optimally at $60^{\circ} \mathrm{C}[38,39]$. The active site of $\mathrm{ALDH}_{\mathrm{Pp}}$ is highly hydrophobic, linked to the enzyme preferring non-polar substrates and converting them more efficiently, e.g., acetaldehyde is the most inefficiently processed. $\mathrm{ALDH}_{\mathrm{Pp}}$ could even process the pyrene ring derived pyrene-1-carboxaldehyde.

ALDH enzymes have the potential to act as a biocatalytic route for carboxylic acid synthesis [40]. Traditional methods for the oxidation of aldehydes to carboxylic acids is no longer sustainable due to the use of stoichiometric amounts of transition metal oxidants, salts or $\mathrm{Ag}_{2} \mathrm{O}$ in combination with sodium cyanide, besides complicated reaction protocols. Biocatalytic methods employing enzymes are attractive due to the use of mild reaction conditions coupled with the regio- and chemo-selectivity. Investigation of ALDHs in biocatalysis has only been marginally investigated, but their exquisite chemoselectivity and broad substrate scope makes them attractive candidates [40-42]. Additionally, there is a considerable demand for more stable and better performing catalysts, to which an efficient solution is the use of thermophilic enzymes [43].

Previously, the structure of $\mathrm{ALDH}_{\mathrm{Tt}}$ was resolved revealing a tetrameric organisation (Scheme 1) with a distinct C-terminal tail which plays a role in oligomerisation, active site regulation, and thermostability [30]. The tail wraps the opposing monomer in a diagonal fashion, and as it does so it is dragged across the substrate entry channel with possible occlusion of the active site. Even though the structure of this enzyme has been determined, its biochemical characterisation is important to understand and link the structure and function. Herewith, we describe the recombinant expression, purification, and biochemical characterisation of the $\mathrm{ALDH}_{\mathrm{Tt}}$ from $\mathrm{T}$. thermophilus. The aim is to efficiently purify the thermophilic $\mathrm{ALDH}_{\mathrm{Tt}}$ to allow for the investigation of its catalytic ability in terms of substrate specificity and reaction mechanisms. Both dehydrogenase and esterase activity are analysed with a range of possible substrates for enzymatic characterisation of the $\mathrm{ALDH}_{\mathrm{Tt}}$ providing insight into its possible biological roles or use in biocatalysis.

\section{Materials and Methods}

\subsection{Protein Sequence Alignment and BLAST Analysis}

Protein sequences were retrieved from the NCBI database (National Center for Biotechnology Research) (https:/ /www.ncbi.nlm.nih.gov/ accessed on 1 November 2021) and aligned in multiple sequence format using the Clustal Omega multiple sequence alignment tool (https:/ / www.ebi.ac.uk/Tools/msa/clustalo/ accessed on 5 November 2021). The protein sequence alignments were visualised using GeneDoc software. The basic local alignment search tool (BLAST) was carried out for $\mathrm{ALDH}_{\mathrm{Tt}}$ utilising the NCBI's protein BLAST search (https:/ / blast.ncbi.nlm.nih.gov / Blast.cgi accessed on 9 December 2021). Sequences for alignment were obtained from NCBI for $\mathrm{ALDH}_{\mathrm{Tt}}(6 \mathrm{FJX})$, human ALDH1A3 (5FHZ) and succinate semialdehyde dehydrogenase (SS-ALDH) from E. coli (3JZ4). 


\subsection{Native $A L D H_{T t}$ Purification with $\mathrm{caa}_{3}$-Oxidase}

Crystalline native $\mathrm{ALDH}_{\mathrm{Tt}}$ was first identified as an impurity, during the crystallisation of the $\mathrm{Caa}_{3}$-cytochrome $\mathrm{c}$ oxidase [30,44]. $\mathrm{ALDH}_{\mathrm{Tt}}$ was purified from the $\mathrm{Caa}_{3}$-oxidase through cation exchange chromatography and ammonium sulfate precipitation.

\section{3. $A L D H_{T t}$ Recombinant Expression and Purification}

The construct DNA pET-22b(+)-ALDH $\mathrm{Tt}_{\mathrm{Tt}}$ [30] was transformed via heat shock at $42{ }^{\circ} \mathrm{C}$ into E. coli BL21(DE3) competent cells (Invitrogen). Expression of $\mathrm{ALDH}_{\mathrm{Tt}}$ was performed in ZYP-5052 auto induction media, supplemented with ampicillin $(50 \mu \mathrm{g} / \mathrm{mL})$, and inoculated with $1 \%(\mathrm{v} / \mathrm{v})$ of overnight culture of transformed cells in LB broth grown at $37^{\circ} \mathrm{C}$. Expression was carried out for $48 \mathrm{~h}$ at $25^{\circ} \mathrm{C}, 200 \mathrm{rpm}$, with subsequent cell collection at $6000 \times \mathrm{g}, 4^{\circ} \mathrm{C}$ for $15 \mathrm{~min}$. The cell pellet was resuspended in lysis buffer containing $20 \mathrm{mM}$ Tris- $\mathrm{HCl} \mathrm{pH} \mathrm{7.5,} 5 \mathrm{mM} \beta$-mercaptoethanol, $10 \mathrm{mM}$ imidazole, and $500 \mathrm{mM} \mathrm{NaCl}$, with $5 \mathrm{~mL}$ added per $\mathrm{g}$ of cells. The lysis buffer was supplemented with $0.25 \mathrm{mg} / \mathrm{mL}$ lysozyme, $20 \mu \mathrm{g} / \mathrm{mL}$ DNase I, and $200 \mathrm{mM} \mathrm{MgCl}_{2}$, and frozen at $-80{ }^{\circ} \mathrm{C}$ overnight. Following overnight freezing, the cells were thawed, sonicated, heat treated at $65^{\circ} \mathrm{C}$ for $15 \mathrm{~min}$, and collected by centrifugation at $17,000 \mathrm{rpm}, 4^{\circ} \mathrm{C}$ for $30 \mathrm{~min}$. The soluble fraction was filtered through a $0.45 \mu \mathrm{m}$ nylon filter and loaded onto an XK 16/20 column containing chelating Sepharose fast flow activated with $0.2 \mathrm{M} \mathrm{NiSO}_{4}$, and preequilibrated with $20 \mathrm{mM}$ Tris- $\mathrm{HCl} \mathrm{pH} 7.5,5 \mathrm{mM} \beta$-mercaptoethanol, $10 \mathrm{mM}$ imidazole, and $200 \mathrm{mM} \mathrm{NaCl}$ for affinity chromatography. Bound proteins were eluted using a step gradient of imidazole at concentrations of 50, 100, 200, and $500 \mathrm{mM}$ in $20 \mathrm{mM}$ Tris$\mathrm{HCl}, 5 \mathrm{mM} \beta$-mercaptoethanol and $150 \mathrm{mM} \mathrm{NaCl}, \mathrm{pH}$ 7.5. Fractions containing the $\mathrm{ALDH}_{\mathrm{Tt}}$ were dialysed overnight at $4{ }^{\circ} \mathrm{C}$ against $50 \mathrm{mM}$ Tris- $\mathrm{HCl}, 5 \mathrm{mM} \beta$-mercaptoethanol and $250 \mathrm{mM} \mathrm{NaCl}, \mathrm{pH} 7.5$, and concentrated using Amicon Ultra-15 centrifugal filters, $50 \mathrm{kDa}$ MWCO (Merck Millipore). Approximately $1 \mathrm{~mL}$ of concentrated protein was loaded onto a HiLoad 16/60 Superdex $200 \mathrm{pg}$ column, pre-equilibrated with $50 \mathrm{mM}$ Tris- $\mathrm{HCl} \mathrm{pH}$ $7.5,5 \mathrm{mM} \beta$-mercaptoethanol and $150 \mathrm{mM} \mathrm{NaCl}$. The eluted fraction was concentrated to a desired concentration $(25-30 \mathrm{mg} / \mathrm{mL})$, snap-frozen in liquid nitrogen, and stored at $-80{ }^{\circ} \mathrm{C}$ until further use.

\subsection{SDS-PAGE and Western Blot}

Protein samples were run on a 12\% SDS-PAGE gel, stained using Instant Blue (Sigma) and destained in deionised water overnight. For Western blot, proteins were transferred from an unstained gel to nitrocellulose membrane at $80 \mathrm{mAmp}$ for $90 \mathrm{~min}$, followed by subsequent blocking and washing steps. The $\mathrm{ALDH}_{\mathrm{Tt}}$ was coupled with an anti-6xhis-HRP antibody, followed by colorimetric detection utilising the substrate 5-Tetramethylbenzidine (TMB).

\subsection{MALDI-TOF Mass Spectrometry}

The molecular mass of the $\mathrm{ALDH}_{\mathrm{Tt}}$ was confirmed by matrix-assisted laser desorption ionisation-time of flight (MALDI-TOF) mass spectrometry using $\alpha$-cyano-4-hydroxycinnamic acid (HCCA) as the matrix. The $\operatorname{ALDH}_{\mathrm{Tt}}(31.12 \mathrm{mg} / \mathrm{mL})$ was diluted 1 in 30 in water to minimise the presence of salts before analysis. A $1 \mu \mathrm{L}$ aliquot of protein solution was added to $1 \mu \mathrm{L}$ of the HCCA matrix, with $1 \mu$ of sample then added to the steel sample plate. The sample plate was inserted into the MALDI-TOF Ultraflex mass spectrometer (Bruker) and run in linear cationic 5-60 kDa mode, using 2500 shots. The theoretical molecular mass was determined using Expasy online molecular weight calculation tools (https: / /web.expasy.org accessed on 1 November 2021) and amino acid sequencing of $\mathrm{ALDH}_{\mathrm{Tt}}(6 \mathrm{FJX})$ from NCBI.

\subsection{Activity Assessment-Temperature and $p H$}

The catalytic activity of $\mathrm{ALDH}_{\mathrm{Tt}}$ was determined spectrophotometrically at $340 \mathrm{~nm}$ by measuring the increase in absorbance due to the production of NADH by the enzyme. The reaction mixture was analysed in a plastic cuvette at $50{ }^{\circ} \mathrm{C}$ and consisted of $2 \mathrm{mM}$ 
$\mathrm{NAD}^{+}, 40 \mu \mathrm{L}$ of $0.38 \mathrm{mg} / \mathrm{mL} \mathrm{ALDH} \mathrm{Tt}_{\mathrm{Tt}}, 10 \mathrm{mM}$ potassium phosphate at a $\mathrm{pH}$ of 8 , and $2 \mathrm{mM}$ hexanal in a final reaction volume of $1.8 \mathrm{~mL}$, unless otherwise stated. All $\mathrm{ALDH}_{\mathrm{Tt}}$ reactions were continuously monitored for $2 \mathrm{~min}$ at $340 \mathrm{~nm}$. The activity of $\mathrm{ALDH}_{\mathrm{Tt}}$ was examined over a temperature range from 20 to $50{ }^{\circ} \mathrm{C}$; higher temperatures were not utilised due to the volatility and flammability of the aldehyde substrates. All solutions (with the exception of the enzyme) were heated to the appropriate temperature in a water bath before use. Measurements were taken utilising a Cary60 UV-vis spectrophotometer equipped with a temperature controller. The activity of $\mathrm{ALDH}_{\mathrm{Tt}}$ was also examined over a $\mathrm{pH}$ range of 2-10 using various buffers; $\mathrm{pH} 2$ (10 mM potassium chloride- $\mathrm{HCl}$ buffer); $3-5$ (10 mM citrate buffer); 6-8 (10 mM potassium phosphate); and 9-10 (10 mM Tris-HCl buffer).

\subsection{Substrate Screening of Aldehydes}

Model aliphatic (hexanal) [30] and aromatic (benzaldehyde) substrates were tested for activity with the $\mathrm{ALDH}_{\mathrm{Tt}}$ to first identify the substrate scope of the enzyme. Once conversion of both substrates was identified, in silico screening of aldehyde substrates was carried out, resulting in a library of 12 aliphatic, cyclic and aromatic aldehydes (Table S1) for use in enzymatic activity testing of the $\mathrm{ALDH}_{\mathrm{Tt}}$ for determination of substrate specificity. The catalytic activity of $\mathrm{ALDH}_{\mathrm{Tt}}$ was determined spectrophotometrically at $340 \mathrm{~nm}$ by measuring the increase in absorbance due to the production of NADH. The activity of $\mathrm{ALDH}_{\mathrm{Tt}}$ for each of the 12 substrates was first analysed at $25{ }^{\circ} \mathrm{C}$ and further at $50{ }^{\circ} \mathrm{C}$. The reaction mixture was analysed in a plastic cuvette, and consisted of $10 \mathrm{mM}$ potassium phosphate buffer $\mathrm{pH} 8,2 \mathrm{mM} \mathrm{NAD}^{+}, 40 \mu \mathrm{L}$ of $0.38 \mathrm{mg} / \mathrm{mL} \mathrm{ALDH}_{\mathrm{Tt}}$, and $2 \mathrm{mM}$ of each substrate ( $1 \mathrm{mM}$ for terephthalaldehyde due to solubility concerns) in a final reaction volume of $1.8 \mathrm{~mL}$. All enzymatic assays were continuously monitored for $2 \mathrm{~min}$.

\subsection{ALDH $_{T t}$ Reduction Reaction}

The action of $\mathrm{ALDH}_{\mathrm{Tt}}$ for the reduction of carboxylic acids to aldehydes utilising $\mathrm{NADH}$ was investigated. The reduction reaction was determined spectrophotometrically by monitoring the decrease in absorbance at $340 \mathrm{~nm}$ due to the conversion of NADH to $\mathrm{NAD}^{+}$. The reaction mixture consisted of $10 \mathrm{mM}$ potassium phosphate $\mathrm{pH} 8,40 \mu \mathrm{L}$ of $0.38 \mathrm{mg} / \mathrm{mL} \mathrm{ALDH} \mathrm{Tt}_{\mathrm{t}}, 150 \mu \mathrm{M}$ NADH and either hexanoic acid $(2 \mathrm{mM})$ or terephthalic acid $(0.12 \mathrm{mM})$, with the reaction monitored for $5 \mathrm{~min}$ at $50{ }^{\circ} \mathrm{C}$.

\subsection{Determination of Kinetic Parameters}

Michaelis-Menten kinetics analysis was carried out for hexanal, benzaldehyde, and terephthalaldehyde, using the assay conditions outlined above at 25 and $50{ }^{\circ} \mathrm{C}$ varying substrate concentration. The ranges of concentrations used were as follows: $0.1-2 \mathrm{mM}$ hexanal, 0.2-3.5 $\mathrm{mM}$ benzaldehyde, and 0.025-1 $\mathrm{mM}$ terephthalaldehyde.

Michaelis-Menten kinetics analysis for $\mathrm{NAD}^{+}$was carried out using $2 \mathrm{mM}$ hexanal at 25 and $50{ }^{\circ} \mathrm{C}$. The $\mathrm{NAD}^{+}$concentration varied from $1-200 \mu \mathrm{M}$.

\subsection{HPLC Detection of Hexanoic Acid}

To further demonstrate the catalytic mechanism of the $\mathrm{ALDH}_{\mathrm{Tt}}$, the model substrate hexanal was utilised for conversion to hexanoic acid with direct detection of the carboxylic acid product via HPLC. An Agilent 1260 Infinity Series (Aglient Technologies, Palo Alto, Santa Clara, CA, USA) was used for HPLC analysis and the acquired data was processed with the Agilent OpenLAB CDS software. Chromatographic separations for the detection of hexanoic acid from $\mathrm{ALDH}_{\mathrm{Tt}}$ enzymatic assays were carried out using an Agilent MicrosorbMV 100-5 C18 column $(250 \times 4.6 \mathrm{~mm})$. The system was maintained at $30{ }^{\circ} \mathrm{C}$ with a run time of $10 \mathrm{~min}$. The mobile phase which comprised of A: $10 \mathrm{mM}$ potassium phosphate, phosphoric acid at a pH of 2.4, and B: HPLC gradient grade acetonitrile (Sigma Aldrich, Co. Wicklow, Ireland) (A:B, 60:40, v/v) was delivered to the column at a flow rate of $1 \mathrm{~mL} / \mathrm{min}$, which yielded a column back pressure of $\sim 190$ bar. Samples were filtered through $0.45 \mu \mathrm{m}$ 
nylon filters and $60 \mu \mathrm{L}$ injections were made. UV detection was conducted at a wavelength of $210 \mathrm{~nm}$.

\subsection{Esterase Activity}

$\mathrm{ALDH}_{\mathrm{Tt}}$ was purified in the absence of $\beta$-mercaptoethanol for esterase activity assessment in order to prevent artefactual catalysis of the ester. Following the nickel affinity chromatography step, the fractions containing $\mathrm{ALDH}_{\mathrm{Tt}}$ were dialysed overnight against $50 \mathrm{mM}$ Tris- $\mathrm{HCl}, 250 \mathrm{mM} \mathrm{NaCl}, \mathrm{pH}$ 7.5, and subsequently loaded onto a HiLoad 16/60 Superdex $200 \mathrm{pg}$ column pre-equilibrated with $50 \mathrm{mM}$ Tris- $\mathrm{HCl}$ with a $\mathrm{pH}$ of 7.5 , and $150 \mathrm{mM} \mathrm{NaCl}$, snap frozen in liquid nitrogen and stored at $-80{ }^{\circ} \mathrm{C}$. To facilitate direct comparison of the esterase and dehydrogenase reaction rates, both activities were determined using protein samples purified without $\beta$-mercaptoethanol. The reactions were conducted in $10 \mathrm{mM}$ potassium phosphate $\mathrm{pH} 8.0$ at $25^{\circ} \mathrm{C}$ unless otherwise stated. Two ester substrates were examined with $\mathrm{ALDH}_{\mathrm{Tt}}$ at concentrations of $1 \mathrm{mM}$ for $p$-nitrophenyl acetate (PNP-acetate) and $500 \mu \mathrm{M}$ of $p$-nitrophenyl butyrate (PNP-butyrate). Standard solutions of PNP-acetate were prepared with acetone as a solvent to minimise spontaneous hydrolysis. Stock concentrations were selected so that the acetone concentration in the assay solutions did not exceed $0.1 \%$. When direct comparison between the two activities was desired, a comparable acetone concentration was added to the standard assay system for dehydrogenase activity using hexanal. Esterase activity was monitored spectrophotometrically at $400 \mathrm{~nm}$ by measuring the increase in absorbance due to the production of the $p$-nitrophenoxide ion by the enzyme. All esterase data was corrected for the minor rate of spontaneous hydrolysis of substrate in the absence of enzyme (blank rate). A pH dependent extinction coefficient of $17 \times 10^{3} \mathrm{M}^{-1} \mathrm{~cm}^{-1}$ was calculated via a calibration curve of $p$-nitrophenol in $10 \mathrm{mM}$ potassium phosphate $\mathrm{pH} 8,0.1 \%$ acetone $(\mathrm{pKa}=7.1)$ (Figure S1).

\section{Results}

The 59 kDa his-tagged ALDH $\mathrm{Tt}_{\mathrm{T}}$ was overexpressed in E. coli BL21(DE3), and purified to apparent homogeneity using IMAC and gel filtration chromatography. Enzymatic activity assessments were carried out to determine the enzyme's optimum $\mathrm{pH}$ and temperature for catalysis. In addition, 12 aldehyde substrates were tested for efficient conversion by the $\mathrm{ALDH}_{\mathrm{Tt}}$, with eight aliphatic, aromatic, and dialdehydes demonstrating catalytic activity. This sample pool of substrates demonstrated that the $\mathrm{ALDH}_{\mathrm{Tt}}$ is not substrate specific, and indicates the capabilities of $\mathrm{ALDH}_{\mathrm{Tt}}$ in terms of its substrates scope. $\mathrm{ALDH}_{\mathrm{Tt}}$ was also examined for esterase activity demonstrating conversion of PNP-acetate and PNP-butyrate reliant on the absence of cofactor. Esterase activity occurred at a much lower rate than dehydrogenase activity, a common characteristic of ALDHs.

\subsection{Protein Sequence Alignment}

BLAST search of the $\mathrm{ALDH}_{\mathrm{Tt}}$ allowed for determination of its closest related homolog based on sequence identity. The putative ALDH from the thermophile Thermus parvatiensis with 529 amino acids resulted in a sequence identity of $97.92 \%$, and is proposed to display a C-terminal extension characteristic of $\mathrm{ALDH}_{\mathrm{Tt}}$. The highest related homologs (86-97\% sequence identity) were all members of the Thermus genus, but none have been characterised to date. The well-characterised human ALDH1A3 returned a sequence identity of 39.03\% in relation to $\mathrm{ALDH}_{\mathrm{Tt}}$ (Figure S2), the highest identity of ALDHs with resolved structures. The closest mesophilic homolog was that of the SS-ALDH from E. coli, with a sequence identity of $34.30 \%$. Interestingly, both human and mesophilic partners are tetramers similar to $\mathrm{ALDH}_{\mathrm{Tt}}$; however, from the sequence alignment, neither contain a C-terminal extended tail (Figure S2). The ALDH $\mathrm{Tt}_{\mathrm{Tt}}$ is observed to contain an N-terminal deletion compared to ALDH1A3 but not SS-ALDH. 


\subsection{Recombinant $A L D H_{T t}$ Expression and Purification}

Overexpression of $\mathrm{ALDH}_{\mathrm{Tt}}$ was achieved in E. coli BL21(DE3) at $25^{\circ} \mathrm{C}$ for $48 \mathrm{~h}$ (Figure 1a) with detection of the expressed his-tagged protein via Western blot, using anti-6x-his antibodies coupled with horse radish peroxidase for colorimetric detection using the substrate TMB (Figure 1b). The recombinant protein expressed in the cytosol of $E$. coli was purified to apparent homogeneity by lysis, heat treatment, immobilized metal affinity chromatography (IMAC), and gel filtration chromatography yielding approximately $15-20 \mathrm{mg} / \mathrm{L}$ of culture. During $\mathrm{Ni}$ affinity chromatography, $\mathrm{ALDH}_{\mathrm{Tt}}$ eluted at $200 \mathrm{mM}$ imidazole demonstrating substantial purity and efficient separation from host cell proteins (Figures 1a and 2a). The gel filtration elution profile (Figure 2b) demonstrates apparent homogeneity of a tetrameric protein [30] with complete purity demonstrated on the SDS-PAGE (Figure 1a). Comparison of protein yield and purity was performed for the purification protocols with and without the heat treatment step. The fractions collected following Ni chromatography and gel filtration were of similar purity (Figure S3), irrespective of whether heat treatment was applied or omitted. However, the cell lysate of the heat-treated sample demonstrated higher purity with lower amounts of contaminating host proteins. Additionally, an approximate $40 \%$ decrease in protein yield occurred when the heat treatment step was removed from the purification protocol. Through the use of identical expression cultures, the protocol including heat treatment for $15 \mathrm{~min}$ at $65{ }^{\circ} \mathrm{C}$ yielded $13.42 \mathrm{mg} / \mathrm{L}$, and when heat treatment was omitted, $8.18 \mathrm{mg} / \mathrm{L}$ was obtained.

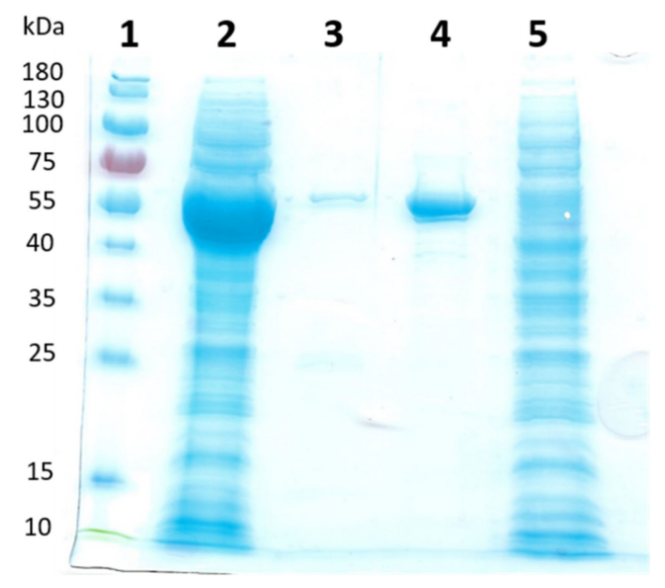

(a)

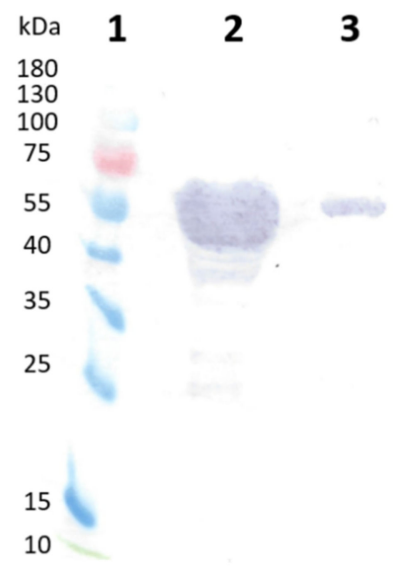

(b)

Figure 1. (a) SDS-PAGE of $\mathrm{ALDH}_{\mathrm{Tt}}$ protein purification samples. Lane 1: PageRuler pre-stained protein ladder (ThermoFisher Scientific, Cork, Ireland), lane 2: E. coli BL21(DE3) cell lysate expressing $\mathrm{ALDH}_{\mathrm{Tt}}$, lane 3: Ni affinity chromatography $200 \mathrm{mM}$ imidazole elution, lane 4: purified $\mathrm{ALDH}_{\mathrm{Tt}}$, lane 5: Ni affinity chromatography flow through. (b) Western blot of cell lysate expressing $\mathrm{ALDH}_{\mathrm{Tt}}$ and purified protein following gel filtration chromatography. Lane 1: PageRuler pre-stained protein ladder (Thermofisher Scientific, Cork, Ireland), lane 2: E. coli BL21(DE3) cell lysate expressing $\mathrm{ALDH}_{\mathrm{Tt}}$, lane 3: purified $\mathrm{ALDH}_{\mathrm{Tt}}$.

\subsection{Determination of $A L D H_{T t}$ Molecular Mass by MALDI-TOF}

The molecular mass of the 530 amino acid $\mathrm{ALDH}_{\mathrm{Tt}}$ with attached his-tag estimated by SDS-PAGE (Figure 1a) agreed with the theoretical molecular mass deduced from the protein sequence (59.379 $\mathrm{kDa})$, calculated using Expasy online molecular weight calculation tools (https: / / web.expasy.org accessed on 1 November 2021) and amino acid sequence (6FJX) from NCBI. MALDI-TOF analysis of the $\mathrm{ALDH}_{\mathrm{Tt}}$ returned a molecular mass of $59.393 \mathrm{kDa}$ (Figure 3) confirming the enzyme's calculated molecular weight, and successful expression and purification of the full-length protein. 


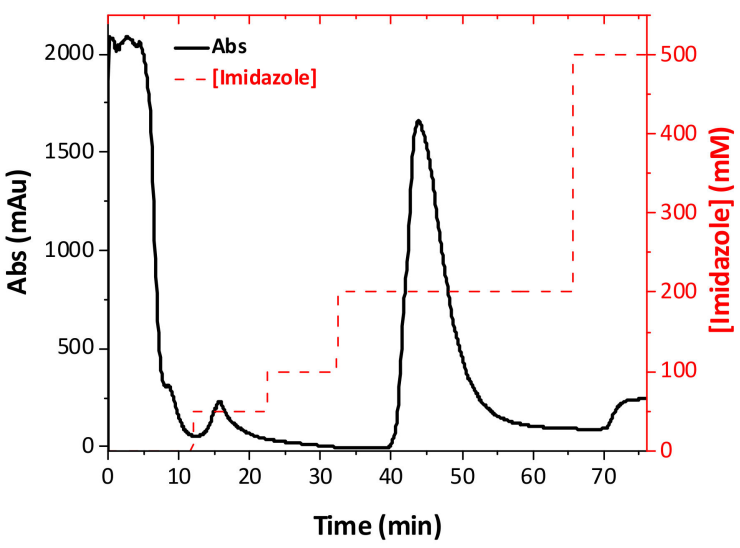

(a)

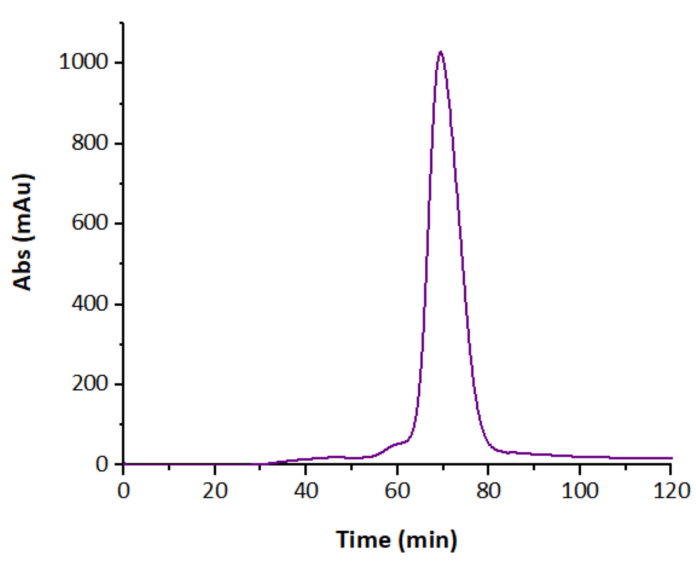

(b)

Figure 2. Elution profile of $\mathrm{ALDH}_{\mathrm{Tt}}$ via Ni-affinity chromatography and gel filtration chromatography. Absorbance was monitored at $280 \mathrm{~nm}$. (a) Chromatogram displaying purification of $\mathrm{ALDH}_{\mathrm{Tt}}$ via Ni-affinity chromatography using a step gradient of imidazole from 50-500 mM. E. coli host proteins are eluted from 10-50 mM imidazole in the first two peaks, while $\mathrm{ALDH}_{\mathrm{Tt}}$ is eluted at $200 \mathrm{mM}$ imidazole in the third peak. (b) Chromatogram displaying a Gaussian peak of the apparent homogenous $\mathrm{ALDH}_{\mathrm{Tt}}$ with elution at approximately $70 \mathrm{~min}$ using gel filtration chromatography at a flow rate of $1 \mathrm{~mL} / \mathrm{min}$.

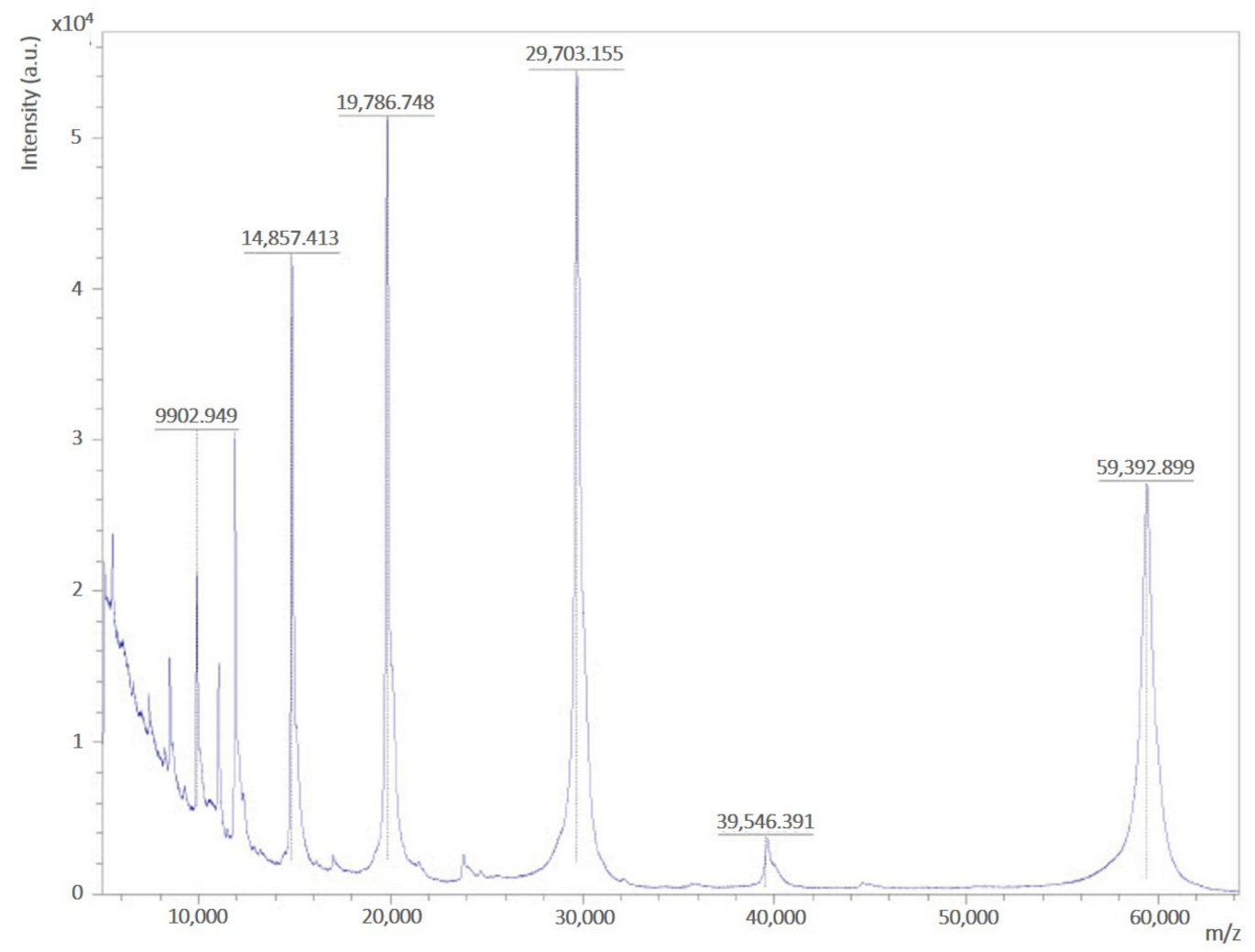

Figure 3. MALDI-TOF spectrum of recombinant $\mathrm{ALDH}_{\mathrm{Tt}}$ utilising $\mathrm{HCCA}$ as the matrix, run in linear cationic 5-60 kDa mode, using 2500 shots.

\subsection{ALDH $_{T t}$ Enzymatic Activity Profiles}

The optimum operation conditions of the $\mathrm{ALDH}_{\mathrm{Tt}}$ were explored, over a range of temperatures and $\mathrm{pH}$ using the model substrate hexanal with $\mathrm{NAD}^{+}$as cofactor. Activity at $20^{\circ} \mathrm{C}$ was 7.2 -fold less than that at $50{ }^{\circ} \mathrm{C}(0.12 \pm 0.003$ and $0.86 \pm 0.03 \mathrm{U} / \mathrm{mg}$, respectively $)$ (Figure $4 \mathrm{a}$ ). The operational $\mathrm{pH}$ range of the enzyme was also examined, with an optimal 
$\mathrm{pH}$ for use of 8 with a specific activity of $0.91 \pm 0.03 \mathrm{U} / \mathrm{mg}$ (Figure $4 \mathrm{~b}$ ). The activity in basic conditions was more favourable than the acidic ones. Over the $\mathrm{pH}$ range of $2-5$, the activity of the enzyme was miniscule. Overall, $10 \%$ of maximum activity was observed at $\mathrm{pH} 5$, while at neutral (6-7) and basic (9-10) $\mathrm{pH}$ the activity was 37 and $54 \%$, respectively, of that at $\mathrm{pH} 8$.

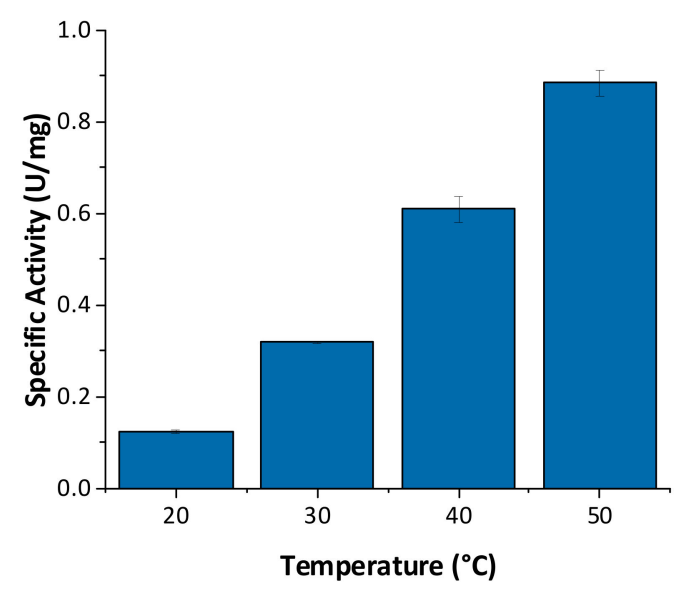

(a)

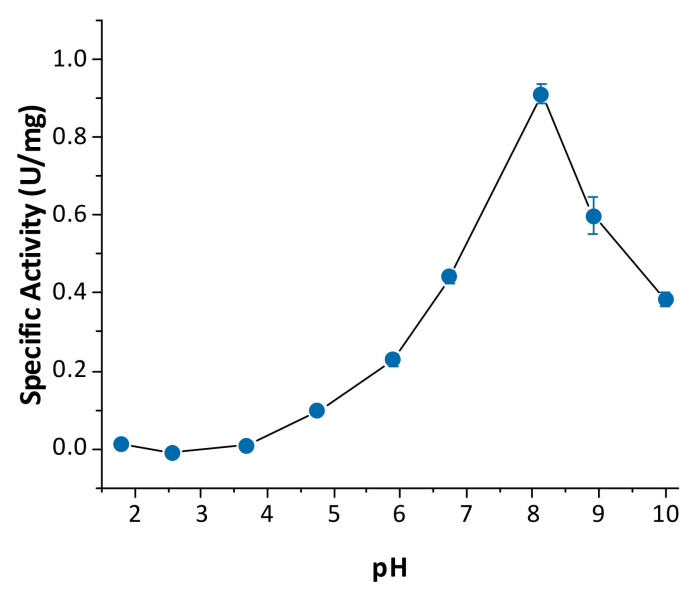

(b)

Figure 4. $\mathrm{ALDH}_{\mathrm{Tt}}$ enzymatic activity profiles utilising $\mathrm{NAD}^{+}$as cofactor and hexanal as substrate (a) Plot of activity of $\mathrm{ALDH}_{\mathrm{Tt}}$ as a function of temperature in the range $20-50{ }^{\circ} \mathrm{C}$ in $10 \mathrm{mM}$ potassium phosphate $\mathrm{pH}$ 8. (b) Plot of activity of $\mathrm{ALDH}_{\mathrm{Tt}}$ as a function of $\mathrm{pH}$ at $50{ }^{\circ} \mathrm{C}$. Optimum conditions were determined as $\mathrm{pH} 8$ at $50{ }^{\circ} \mathrm{C}$.

$\mathrm{ALDH}_{\mathrm{Tt}}$ has recently been reported [30] to possess the highest catalytic activity for the substrate hexanal $(1.08 \pm 0.03 \mathrm{U} / \mathrm{mg})$. Through screening of a range of aldehydes, it was determined that $\mathrm{ALDH}_{\mathrm{Tt}}$ can oxidise aliphatic, aromatic, and dialdehydes, specifically, hexanal, propanal, acetaldehyde, benzaldehyde, $p$-tolualdehyde, trans-cinnamaldehyde, and terephthalaldehyde, at reasonable rates of oxidation (Figure 5 and Table S1). Similar activity, with respect to hexanal at $50{ }^{\circ} \mathrm{C}$, was observed using the synthetic dialdehyde, terephthalaldehyde $(0.88 \pm 0.05 \mathrm{U} / \mathrm{mg})$. Other substrates such as cyclic cyclohexanecarboxaldehyde, 5-hydroxymethyl-2-furfural, and citral displayed no catalytic rate at $25^{\circ} \mathrm{C}$, similar to ortho-substituted benzaldehydes, $o$-tolualdehyde, and 2-chlorobenzaldehyde. Substrates which demonstrated conversion at $25^{\circ} \mathrm{C}$ showed increased specific activity at $50{ }^{\circ} \mathrm{C}$ (approximately 10 -fold (Figure $5 \mathrm{~b}$ )). The substrate cyclohexanecarboxaldehyde that displayed minor and inconsistent catalytic activity at $25^{\circ} \mathrm{C}$ demonstrated a boost in activity at $50{ }^{\circ} \mathrm{C}(0.11 \pm 0.008 \mathrm{U} / \mathrm{mg})$. Moreover, 2-chlorobenzaldehyde showed minor activity at $50^{\circ} \mathrm{C}$; however, with large experimental error $(0.005 \pm 0.004 \mathrm{U} / \mathrm{mg})$. Additionally, $\mathrm{ALDH}_{\mathrm{Tt}}$ dehydrogenase activity is irreversible. No catalytic activity was detected for conversion of hexanoic acid nor terephthalalic acid utilising NADH as cofactor.

$\mathrm{ALDH}_{\mathrm{Tt}}$ follows Michaelis-Menten type mechanism, and the kinetic parameters $\left(\mathrm{K}_{\mathrm{M}}\right.$, $\mathrm{V}_{\max }$ and $\mathrm{k}_{\text {cat }}$ ) for hexanal, benzaldehyde, and terephthalaldehyde were calculated using $\mathrm{NAD}^{+}$as cofactor at both 25 and $50{ }^{\circ} \mathrm{C}$. (Table 1 and Figure S4). The $\mathrm{K}_{\mathrm{M}}$ remained similar at both temperatures across the substrates, with an increase in $\mathrm{V}_{\max }$ and $\mathrm{k}_{\text {cat }}$ observed at $50{ }^{\circ} \mathrm{C}$, as expected. Comparison of the substrates at 25 and $50{ }^{\circ} \mathrm{C}$ demonstrated that terephthalaldehyde displayed the lowest $\mathrm{K}_{\mathrm{M}}(0.11$ and $0.38 \mathrm{mM})$, followed by hexanal (1.08 and $0.99 \mathrm{mM})$ and benzaldehyde $(1.41$ and $1.52 \mathrm{mM})$. The $\mathrm{K}_{\text {cat }}$ values follow a similar trend with the fastest rate demonstrated by terephthalaldehyde $\left(1.05\right.$ and $\left.12.08 \mathrm{~s}^{-1}\right)$, followed by hexanal $\left(0.51\right.$ and $\left.5.71 \mathrm{~s}^{-1}\right)$, with benzaldehyde displaying the slowest turnover number $\left(0.19\right.$ and $1.46 \mathrm{~s}^{-1}$ ) (first value stated in brackets is $25^{\circ} \mathrm{C}$, second is $50{ }^{\circ} \mathrm{C}$ ). The $\mathrm{K}_{\mathrm{M}}$ for the cofactor, $\mathrm{NAD}^{+}$, of $4.7 \mu \mathrm{M}\left(25^{\circ} \mathrm{C}\right)$ and $9.2 \mu \mathrm{M}\left(50^{\circ} \mathrm{C}\right)$, was significantly lower than the substrates trialled, demonstrating increased affinity for the cofactor (Figure S5). 


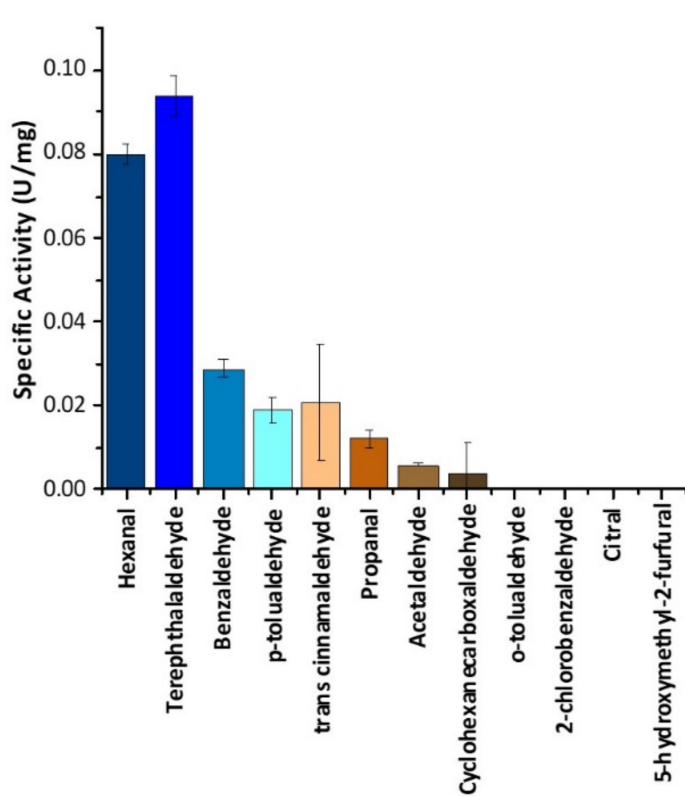

(a)

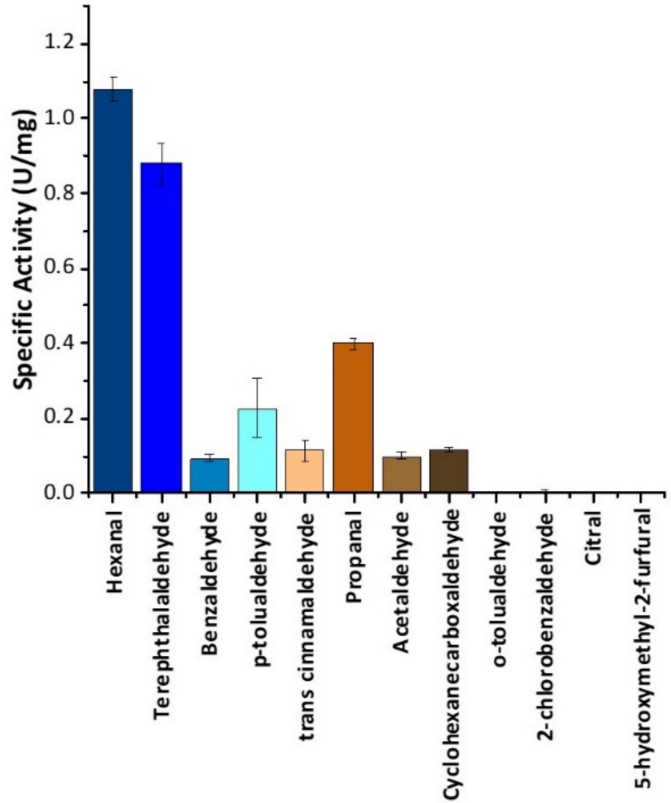

(b)

Figure 5. ALDH $\mathrm{Tt}_{\mathrm{Tt}}$ substrate screening and specificity utilising a range of aliphatic, aromatic, and cyclic aldehydes. Specific activity is demonstrated at (a) $25^{\circ} \mathrm{C}$ and (b) $50^{\circ} \mathrm{C}$, displaying the thermophilic nature and broad substrate scope of the enzyme.

Table 1. Kinetic parameters for $\mathrm{ALDH}_{\mathrm{Tt}}$ using hexanal, terephthalaldehyde and benzaldehyde with NAD ${ }^{+}$

\begin{tabular}{ccccc}
\hline Substrate & ${ }^{\circ} \mathbf{C}$ & $\mathbf{K}_{\mathbf{M}}(\mathbf{m M})$ & $\mathbf{V}_{\mathbf{m a x}}(\mu \mathbf{m o l} / \mathbf{m i n})$ & $\mathbf{k}_{\mathbf{c a t}}\left(\mathbf{s}^{-\mathbf{1}}\right)$ \\
\hline Hexanal & $25^{\circ} \mathrm{C}$ & $1.08 \pm 0.46$ & $0.0021 \pm 0.0006$ & $0.51 \pm 0.15$ \\
& $50^{\circ} \mathrm{C}$ & $0.99 \pm 0.24$ & $0.027 \pm 0.0043$ & $5.71 \pm 0.64$ \\
Terephthalaldehyde & $25^{\circ} \mathrm{C}$ & $0.11 \pm 0.067$ & $0.0041 \pm 0.001$ & $1.05 \pm 0.27$ \\
& $50^{\circ} \mathrm{C}$ & $0.38 \pm 0.11$ & $0.047 \pm 0.010$ & $12.08 \pm 2.50$ \\
Benzaldehyde & $25^{\circ} \mathrm{C}$ & $1.41 \pm 1.15$ & $0.0008 \pm 0.0003$ & $0.19 \pm 0.09$ \\
& $50^{\circ} \mathrm{C}$ & $1.52 \pm 0.51$ & $0.0057 \pm 0.001$ & $1.46 \pm 0.29$ \\
\hline
\end{tabular}

Previous determination of enzymatic conversion of aldehyde and $\mathrm{NAD}^{+}$to carboxylic acid and NADH by the $\mathrm{ALDH}_{\mathrm{Tt}}$ was determined by following NADH production at $340 \mathrm{~nm}$ via UV-Vis spectrophotometry. Here, detection of the carboxylic acid product by HPLC has been performed, to further confirm the $\mathrm{ALDH}_{\mathrm{Tt}}$ reaction mechanism and products formed. A $2 \mathrm{~h}$ enzymatic assay of $\mathrm{ALDH}_{\mathrm{Tt}}$ with hexanal as substrate was run at $50{ }^{\circ} \mathrm{C}$ monitoring production of NADH over time (Figure S6). The resultant product was analysed via HPLC. The ALDH $\mathrm{Tt}_{\mathrm{T}}$ assay contains a number of components, most notably $\mathrm{NAD}^{+}, \mathrm{NADH}$, hexanal, and hexanoic acid. Good separation of these compounds from the hexanoic acid product was achieved allowing for detection of the product. NAD ${ }^{+}$and NADH had a retention time of approximately 2-3 min, hexanal at $4.44 \mathrm{~min}$, and hexanoic acid at $6.86 \mathrm{~min}$. From the $2 \mathrm{~h} \mathrm{ALDH} \mathrm{Tt}_{\mathrm{Tt}}$ assay, hexanoic acid was detected in the assay mixture (Figure S7) confirming dehydrogenase activity by $\mathrm{ALDH}_{\mathrm{Tt}}$.

$\mathrm{ALDH}_{\mathrm{Tt}}$ is capable of acting as an esterase and can catalyse the conversion of $p$ nitrophenyl esters to a carboxylic acid and alcohol. The $\mathrm{ALDH}_{\mathrm{Tt}}$ was purified in the absence of $\beta$-mercaptoethanol, which would typically be present in $5 \mathrm{mM}$ in the final protein formulation. Firstly, dehydrogenase activity of the $\mathrm{ALDH}_{\mathrm{Tt}}$ was tested to ensure the enzyme was catalytically active and stable while omitting $\beta$-mercaptoethanol. Specific activity, for hexanal at $25^{\circ} \mathrm{C}$, of $0.14 \pm 0.01 \mathrm{U} / \mathrm{mg}$ was demonstrated (Figure 6a). The model ester substrate used in esterase activity for ALDH enzymes in the literature is PNP- 
acetate $[9,10,22,45]$; however, its use requires preparation in acetone to avoid spontaneous hydrolysis. The tolerance of $\mathrm{ALDH}_{\mathrm{Tt}}$ dehydrogenase activity to increased levels of acetone $(0.1$ and $5 \%)$ was examined. The rate of oxidation of hexanal by $\mathrm{ALDH}_{\mathrm{Tt}}$ was conserved in $0.1 \%$ acetone; however, a decrease of approx. $23 \%$ was observed in $5 \%$ acetone (Figure $6 \mathrm{a}$ ), requiring the use of stock solutions of PNP-acetate in acetone at concentrations, which, upon addition, would result in $0.1 \%$ acetone in the final reaction volume so as not to disrupt enzyme activity. $\mathrm{ALDH}_{\mathrm{Tt}}$ is active for PNP-acetate, resulting in a specific activity of 0.033 $\pm 0.006 \mathrm{U} / \mathrm{mg}$. In addition, activity was demonstrated for PNP-butyrate, but at the lower rate of $0.013 \pm 0.0002 \mathrm{U} / \mathrm{mg}$ (Table S2). Compared to dehydrogenase activity for hexanal, esterase activity with both esters trialled is significantly slower (Figure 6b), 22.9 and 8.8\% residual activity for PNP-acetate and PNP-butyrate, respectively. Upon calculation of esterase activity, the small background rate of spontaneous hydrolysis of the ester (blank rate) (Figure S8) was removed from the enzymatic rate. Since $\mathrm{ALDH}_{\mathrm{Tt}}$ is thermophilic, esterase activity for PNP-acetate was further analysed at $50^{\circ} \mathrm{C}$, but spontaneous hydrolysis of the substrate at the increased temperature was too high to monitor enzymatic activity (Figure S9), displaying a slope of 0.21, comparable to the enzyme samples. Esterase activity does not require the addition of the $\mathrm{NAD}^{+}$cofactor that dehydrogenase activity by $\mathrm{ALDH}_{\mathrm{Tt}}$ demands. Upon addition of low concentrations of $\mathrm{NAD}^{+}(50 \mu \mathrm{M})$, esterase activity for PNP-acetate was greatly diminished. At levels of $100 \mu \mathrm{M} \mathrm{NAD}^{+}$no esterase activity was evident (Figure 6c).

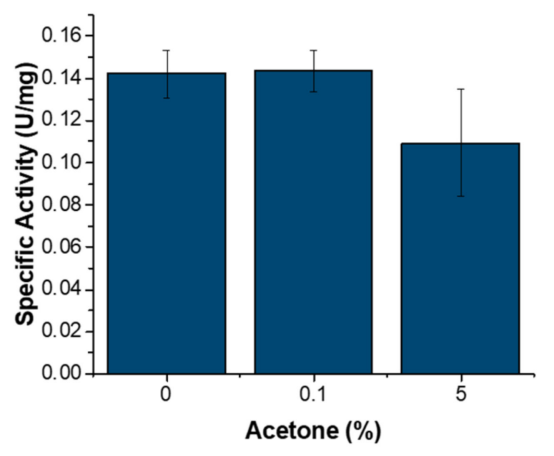

(a)

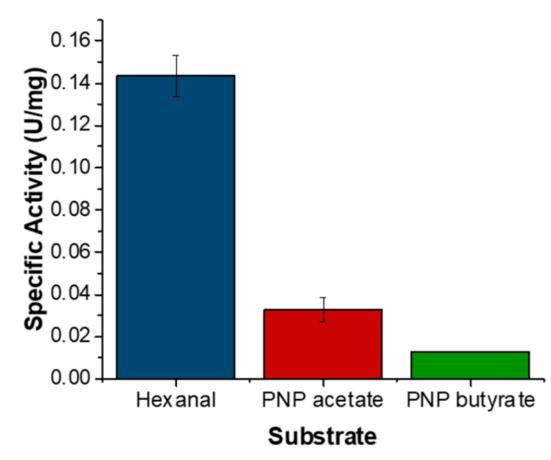

(b)

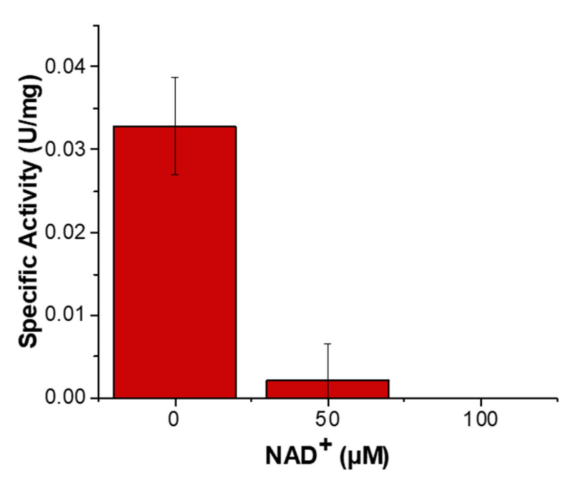

(c)

Figure 6. Dehydrogenase and esterase activity of $\mathrm{ALDH}_{\mathrm{Tt}}$ at $25{ }^{\circ} \mathrm{C}$ purified in the absence of $\beta$-mercaptoethanol (a) dehydrogenase activity using hexanal in the presence of acetone, (b) comparison of specific activity of dehydrogenase and esterase activity using different esters, (c) esterase activity using PNP-acetate in the presence of low concentrations of $\mathrm{NAD}^{+}$.

\section{Discussion}

In 1999, when the focus of ALDH studies was primarily eukaryotic models, a systematic classification system based on protein sequence identity was adopted [46]. This stated that proteins with a sequence identity of above $40 \%$ were members of the same family, while enzymes with a sequence identity above $60 \%$ were members of the same subfamily. Recently, ALDH study has delved into prokaryotic models, demonstrating difficulty in obtaining a sequence identity above $40 \%$, due to the newly recognised diversity of ALDHs as well as the plethora of prokaryotic species. For example, study of the Pseudomonas genus alone lead to the identification of 42 different ALDH classes [31]. BLAST search of $\mathrm{ALDH}_{\mathrm{Tt}}$ resulted in the highest sequence identity for ALDH1A3, while both enzymes display strikingly similar biochemical characteristics [47]. Both $\mathrm{ALDH}_{\mathrm{Tt}}$ and ALDH1A3 are $\mathrm{NAD}^{+}$favouring, soluble enzymes, whose catalytic rate is reduced through use of $\mathrm{NADP}^{+}$cofactor. ALDH1A3 uses the primary substrate retinaldehyde for biosynthesis of retinoic acid. Interestingly, when ALDH1A3 was analysed for activity using non-retinoid aldehydes, hexanal proved to be the best substrate with the highest catalytic efficiency [22]. However, while ALDH1A3 demonstrates a lower $K_{M}$ for hexanal $(6.0 \mu \mathrm{M})$ than NAD $^{+}$ 
$(130 \mu \mathrm{M})$ [22], $\mathrm{ALDH}_{\mathrm{Tt}}$ displays the inverse. ALDH1A3 has a much higher affinity for the hexanal substrate than $\mathrm{ALDH}_{\mathrm{Tt}}$, whereas $\mathrm{ALDH}_{\mathrm{Tt}}$ shows higher affinity for the cofactor. ALDH1A3 also demonstrated esterase activity for PNP-acetate, alike to $\mathrm{ALDH}_{\mathrm{Tt}}$.

Across ALDHs, substrate specificity has been related to the shape and geometry of the substrate entry channel of the enzyme, linked to three key amino acids at distinct positions, termed the "mouth" (136), "neck" (471), and "bottom" (315) (human ALDH1A3 numbering) $[5,22,48]$. ALDH1A3 and ALDH $_{\mathrm{Tt}}$ possess a conserved Thr at the "bottom" residue, and show a conservative substitution of hydrophobic residues at the "neck" (Leu to Ala respectively). This conservative substitution is demonstrated across human ALDH1 family members [22]. A significant exchange of Gly to Glu at the "mouth" in ALDH1A3 vs $\mathrm{ALDH}_{\mathrm{Tt}}$ is evident. The mouth residue typically carries out a size selection function, for example human ALDH2 with the preferred substrate acetaldehyde possesses a bulky Met at this position, while ALDH1A3 using retinaldehyde harbours a Gly [5,48-50]. ALDH $\mathrm{At}_{\mathrm{Tt}}$ with Glu at the "mouth" position might relate to optimal substrates being smaller than retinaldehyde, but larger than acetaldehyde, a trend which was adhered to experimentally with the trialled substrates, e.g., hexanal, trans-cinnamaldehyde, and terephthalaldehyde.

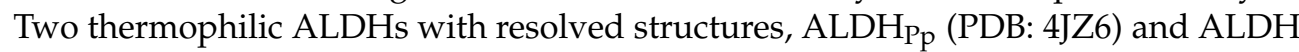
from Thermoproteus tenax $\left(\mathrm{ALDH}_{\mathrm{Ttx}}\right)$ (PDB: $1 \mathrm{UXT}$ ), acquire 30.75 and $29.23 \%$ sequence identity, respectively, compared to $\mathrm{ALDH}_{\mathrm{Tt}}[38,51]$. Both are $\mathrm{NAD}^{+}$favouring enzymes, with $\mathrm{ALDH}_{\mathrm{Pp}}$ acting as a dimer and $\mathrm{ALDH}_{\mathrm{Ttx}}$ as a tetramer. $\mathrm{ALDH}_{\mathrm{Pp}}$ displays broad substrate specificity with the ability to process aliphatic and aromatic aldehydes at high catalytic efficiencies, including hexanal and benzaldehyde. $\mathrm{ALDH}_{\mathrm{Ttx}}$, however, is specific for glyceraldehyde-3-phosphate. Through analysis of a range of thermophilic ALDHs, it was found that they are quite diverse in oligomeric state and substrate specificity. $\mathrm{ALDH}_{\mathrm{Gtv}}$ exists as an octamer, with $\mathrm{ALDH}_{\mathrm{Gtd}}$ displaying a tetrameric formation with the possibility of octamers formed via dimerization of tetramers [35,39]. Overall, thermophilic ALDHs had a high preference for $\mathrm{NAD}^{+}[35,38,39,51,52]$. An exception is the archaeal ALDH from Sulfolobus solfataricus $\left(\mathrm{ALDH}_{\mathrm{Ss}}\right)$ favouring $\mathrm{NADP}^{+}$[53]. The ALDH from Sulfolobus tokodaii $\left(\mathrm{ALDH}_{\mathrm{St}}\right)$ also demonstrated esterase activity for PNP-acetate [52], displaying that thermophilic counterparts also display dual enzymatic activity (discussed further below).

Interestingly, $\mathrm{ALDH}_{\mathrm{Tt}}$ was first co-purified as a contaminant during native $\mathrm{caa}_{3}$-type cytochrome oxidase isolation from T. thermophilus [44]. This is peculiar as, in mammals, ALDH and cytochrome oxidases are linked to the biosynthesis of retinoic acid. In vivo retinoic acid synthesis starts from $\beta$-carotene or all-trans-retinol to produce retinaldehyde, which is then converted to all-trans retinoic acid via ALDH1 isozymes; this is further processed to form 4-hydroxy-retinoic acid utilising cytochrome oxidases. This highlights a biological link between the two enzymes and the possibility of a similar mechanism within T. thermophilus. Additionally, the sequence relation between ALDH1A3 and $\mathrm{ALDH}_{\mathrm{Tt}}$ further highlights this possibility as ALDH1A3's primary substrate is retinaldehyde. However, retinoid signalling mechanisms are generally considered to be of animal origin, and to date it has only been characterised in animals. More recently, retinoic acid was identified within prokaryotic models, including Bacillus cereus [37] and cyanobacteria [36], exhibiting a potential biological role of retinoic acid in prokaryotes. It was hypothesised that perhaps the retinoic acid signalling pathway first existed in cyanobacteria and now exists in humans through a lateral gene transfer event of ALDH and CYP120 [36,54], which was also hypothesised for other proteins [55-57]. The cyanobacteria Chlorogloeopsis fritschii PCC 6912 possesses three orthologs of the enzymes responsible for the conversion of $\beta$-carotene to retinoic acid in the signalling pathway recognised in animals. Interestingly, the ALDH was recognised to convert retinaldehyde to retinoic acid suggesting evidence of the use of the pathway in prokaryotic models, and one of the possible functional roles of $\mathrm{ALDH}_{\mathrm{Tt}}$.

Recombinant expression and purification of $\mathrm{ALDH}_{\mathrm{Tt}}$ proved an efficient method for the production of the full-length enzyme displaying high purity, while also obtaining high production yields. Heat precipitation protocols have been regularly incorporated as a selective purification step for thermostable proteins expressed in mesophilic hosts [53,58-61], 
and has proven effective with other T. thermophilus proteins expressed in E. coli, including other dehydrogenases and the ALDH family member 1-pyrroline-5-carboxylate dehydrogenase $\left(\mathrm{P}_{5} \mathrm{CDH}_{\mathrm{Tt}}\right)$ [61-63]. The heat treatment step of purification of alcohol dehydrogenase, from $T$. thermophilus, at $75{ }^{\circ} \mathrm{C}$ for 15 min was deemed the most efficient step, enriching the enzyme 11-fold, and resulting in $47 \%$ yield of a homogeneous protein [61]. Similarly, isocitrate dehydrogenase was purified by heating at $70{ }^{\circ} \mathrm{C}$ for $20 \mathrm{~min}$, resulting in $80 \%$ purification and increased yields [63] (exact figures not stated), compared to previous reports utilising purification mechanisms from native T. thermophilus. Heat treatment is a promising step to include in a purification protocol, as it does not involve any chemical reagents while also denaturing and aggregating host proteins. In addition, cellular proteases are often denatured, removing their threat to the desired protein product, and thus increasing product yield. Previous studies have demonstrated that addition of heat treatment steps to purification protocols can allow for increased yield and purity $[64,65]$. Heat treatment can further facilitate release of protein product from undisrupted E. coli cells increasing the overall yield of the process [66]. However, the process must be optimised so as not to denature the protein of interest. In this protocol, for $\mathrm{ALDH}_{\mathrm{Tt}}$ purification, the heat treatment step occurs before the removal of cell debris, and acts not only as a method for inactivation of host cell proteins, but also as an additional cell disrupting mechanism. A previous report outlined how increased purity and yield of recombinant thermophilic catalase from Bacillus sp. expressed in E. coli was achieved via heat treatment purification at $65^{\circ} \mathrm{C}$ for $2 \mathrm{~h}$, resulting in a three-fold increase in specific activity of the cell supernatant [59]. Three temperatures were trialled for purification, 55,60 , and $65^{\circ} \mathrm{C}$, demonstrating increased catalase purity with increased temperature. However, when $70^{\circ} \mathrm{C}$ was utilised, catalase was denatured and precipitated, outlining the importance of optimisation. This was also highlighted through purification of ribose-5-phosphate isomerase from Thermotoga maritima where buffer choice, temperature, and treatment time were extensively optimised to achieve high purity $(95 \%)$ and high yields (44.8 mg/L) [58]. Previous reports have also discussed the efficient use of heat treatment purification for mesophilic proteins, such as hepatitis B core antigen and unstructured regions of the proteins epsin 1 and AP180, with an increase in yield in the range of $18-106 \%[64,65]$.

As a thermophilic enzyme, the specific activity of $\mathrm{ALDH}_{\mathrm{Tt}}$, is strongly affected by temperature. It is expected that the specific activity of $\mathrm{ALDH}_{\mathrm{Tt}}$ would increase further at elevated temperatures up to $80^{\circ} \mathrm{C}$, given the optimum growth conditions of $T$. thermophilus $[67,68]$. However, temperatures exceeding $50{ }^{\circ} \mathrm{C}$ were not utilised due to volatility and flammability of the aldehyde substrates. In addition, the operable $\mathrm{pH}$ range demonstrated mimics the optimal growth conditions of the bacterium, favouring neutral $\mathrm{pHs}$ with optimum enzymatic activity achieved at $\mathrm{pH}$ 8. Investigation of other enzymes from T. thermophilus demonstrated similar trends with respect to effect of temperature and $\mathrm{pH}[6,61,69]$. $\mathrm{P}^{2} \mathrm{CDH}_{\mathrm{Tt}}$ was also assayed at $50{ }^{\circ} \mathrm{C}$ using the substrate $\Delta^{1}$-pyrroline-5carboxylate with enzymatic activity observed in the $\mathrm{pH}$ range of $6-10$, with a broad optimum from 7-10 [6]. An alcohol dehydrogenase [61] and glutamate racemase [69] from T. thermophilus showed highest catalytic activity at a $\mathrm{pH}$ between 9-10, with little or no activity present in acidic conditions. The enzymes demonstrated their highest specific activity at 73 and $85^{\circ} \mathrm{C}$, respectively. Thermophilic ALDHs tend to work best under neutral to basic conditions at temperatures from $50-80{ }^{\circ} \mathrm{C}$, as demonstrated by $\mathrm{P}^{\circ} \mathrm{CDH}_{\mathrm{Tt}}$ above. Other examples include, $\mathrm{ALDH}_{\mathrm{Gtv}}$, which works optimally at $55^{\circ} \mathrm{C}, \mathrm{pH} 10$ [35], $\mathrm{ALDH}_{\mathrm{Pp}}$ at $60{ }^{\circ} \mathrm{C}, \mathrm{pH} 8.5$ [38], and $\mathrm{ALDH}_{\mathrm{Gtd}}$ at $60^{\circ} \mathrm{C}, \mathrm{pH} 8$ [39]. Interestingly, the former two of these ALDHs were not stable once a temperature of $70^{\circ} \mathrm{C}$ was reached, with $\mathrm{ALDH}_{\mathrm{Gtd}}$ displaying $56 \%$ residual activity following incubation at $70{ }^{\circ} \mathrm{C}$ for $1 \mathrm{~h}$. In comparison $\mathrm{ALDH}_{\mathrm{Ss}}$ was assayed at $70{ }^{\circ} \mathrm{C}, \mathrm{pH} 7$ [53] and $\mathrm{ALDH}_{\mathrm{St}}$ at $80{ }^{\circ} \mathrm{C}, \mathrm{pH} 8$ [52].

Many ALDH enzymes are reported as being non-specific for substrate, demonstrating catalytic activity with a range of natural and synthetic aldehydes, including thermophilic members [16,22,38-40,52,70,71]. ALDH ${ }_{\mathrm{Tt}}$ could convert aliphatic and aromatic aldehydes, para-substituted benzaldehydes could be efficiently converted by $\mathrm{ALDH}_{\mathrm{Tt}}$, while ortho- 
substituted benzaldehydes demonstrated no catalytic activity. Previous reports outline that ortho-substituted benzaldehydes can result in reduced ALDH activity due to steric hindrance effects around the aldehyde group, particularly when the associated substitution group is bulky $[16,40]$. Thermophilic $\mathrm{ALDH}_{\mathrm{Gtd}}$ could process 2-chlorobenzaldehyde and $o$-phthalaldehyde, but at low residual activities, compared to formaldehyde of 28.4 and $10.8 \%$, respectively [39], while $\mathrm{ALDH}_{\mathrm{Pp}}$ could also convert ortho-substituted benzaldehydes [38]. The thermophilic enzymatic action of the $\mathrm{ALDH}_{\mathrm{Tt}}$ at $50{ }^{\circ} \mathrm{C}$ was maintained with the selection of substrates, highlighting that substrate specificity is not dependent on temperature.

$\mathrm{ALDH}_{\mathrm{Tt}}{ }^{\prime}$ s broad substrate specificity coupled with its increased specific activity at elevated temperatures makes it an attractive target for industrial synthesis of carboxylic acids via biocatalytic mechanisms. Its thermostability will allow for its use in biocatalysis at temperatures where mesophilic counterparts may be unstable or become denatured. The substrate scope of $\mathrm{ALDH}_{\mathrm{Tt}}$ provides a range of interesting potential carboxylic acid products, most notably terephthalic acid and $p$-toluic acid, which are used as a precursor in polyethylene terephthalate (PET) plastic manufacture and as an intermediate in terephthalic acid and polymer synthesis, respectively [72,73].

It was previously demonstrated that $\mathrm{ALDH}_{\mathrm{Tt}}$ has a significant preference for $\mathrm{NAD}^{+}$ cofactor rather than $\mathrm{NADP}^{+}$, displaying $33.4 \%$ residual activity when $\mathrm{NADP}^{+}$is used with hexanal at $50{ }^{\circ} \mathrm{C}[30]$, a trend mostly adhered to by thermophilic ALDHs. As reported for other ALDHs $[47,53,74]$ the $\mathrm{K}_{\mathrm{M}}$ for $\mathrm{NAD}^{+}$is significantly lower than that of the substrates analysed. The $\mathrm{K}_{\mathrm{M}}$ for terephthalaldehyde was significantly lower than the other two substrates, possibly indicative of its dialdehyde nature and the availability of extra aldehyde groups for binding to the $\mathrm{ALDH}_{\mathrm{Tt}}$. In contrast, benzaldehyde with only one aldehyde group but a similar structure has a higher $\mathrm{K}_{\mathrm{M}}$ than terephthalaldehyde. Similar results were obtained using $\mathrm{ALDH}_{\mathrm{Gc}}$ [16], where the activity of the enzyme increased 3.6-fold when using the dialdehyde terephthalaldehyde versus benzaldehyde. Additionally, when a similar substrate, terephthalaldehylic acid, consisting of one aldehyde group and one carboxylic acid group, was used by $\mathrm{ALDH}_{\mathrm{Gc}}$, it decreased by 14.3- and 51.0-fold with respect to benzaldehyde and terephthalaldehyde. This further highlights the use of the two aldehyde groups on dialdehydes by ALDHs for decreased $\mathrm{K}_{\mathrm{M}}$, and increased specific activity. Furthermore, when $\mathrm{ALDH}_{\mathrm{Gc}}$ utilised dialdehydes with ortho-substituted $\mathrm{Br}$, its specific activity was comparable to benzaldehyde (113-115\% residual activity) due to the availability of the second aldehyde group for processing, whereas o-bromobenzaldehyde only demonstrated $8 \%$ residual activity compared to benzaldehyde. However, $\mathrm{ALDH}_{\mathrm{Gc}}$ demonstrated miniscule residual activity $(<1 \%)$ for $o$-phthalaldehyde, constructed by a benzaldehyde with an ortho-substitution of the second aldehyde group. Here, the availability of both aldehyde groups is occluded due to steric hindrance, resulting in minor specific activity.

$\mathrm{ALDH}_{\mathrm{Tt}}$ has dual dehydrogenase and esterase activity and can act independently on aldehyde or $p$-nitrophenyl ester substrates. The esterase activity of ALDHs was first realised in human [75] and horse liver [9] ALDH, and there is evidence that both activities take place within one active site [12]. An array of ALDHs have demonstrated esterase activity for the substrate PNP-acetate to form acetic acid and $p$-nitrophenol, including prokaryotic models $[2,22,52,76,77]$. However, the rate of esterase activity of ALDHs is often much lower than their associated dehydrogenase activity. A residual activity of $1-15 \%$ is common [76,78]. $\mathrm{ALDH}_{\mathrm{Tt}}$ displayed esterase activity for the conversion of two ester substrates, PNP-acetate and PNP-butyrate, without requiring the addition of $\mathrm{NAD}^{+}$cofactor. Throughout the literature, it is highlighted that the addition of $\mathrm{NAD}^{+}$ can either accelerate the ALDH esterase reaction or inhibit it, depending on the isozyme in question $[9,10,15,78,79]$. Low concentrations of cofactor activated the esterase reaction of sheep ALDH1; however, concentrations above $200 \mu \mathrm{M}$ slowed the reaction. A study demonstrated that human mitochondrial ALDH2's esterase action is accelerated by low concentrations of $\mathrm{NAD}^{+}(2.5$ fold with $200 \mu \mathrm{M})$, whereas the same concentrations 
(50-200 $\mu \mathrm{M})$ nearly abolished human ALDH3 esterase activity [15]. This likely highlights that $\mathrm{ALDH}_{\mathrm{Tt}}$ acquires a rate-limiting step characteristic of human ALDH3 enzymes for the esterase reaction; however, its closest related homolog by sequence identity was the human ALDH1A3. In the presence of $500 \mu \mathrm{M} \mathrm{NAD}^{+}$ALDH1A3 exhibited esterase activity for PNP-acetate [22]. Again, this suggests that prokaryotic ALDH models are unique in their own right, and might contain a cross-over of characteristics from distinct mammalian classes and models. Interestingly, the thermophilic $\mathrm{ALDH}_{\mathrm{St}}$ displayed esterase activity for PNP-acetate, and was also inhibited by $\mathrm{NAD}^{+}$[52]. Esterase activity by this enzyme was reduced by $90 \%$ in the presence of $500 \mu \mathrm{M} \mathrm{NAD}^{+}$and activity was abolished at a concentration of $1 \mathrm{mM}$.

\section{Conclusions}

In summary, it can be concluded that the tetrameric $\mathrm{ALDH}_{\mathrm{Tt}}$ from T. thermophilus is a bifunctional enzyme with inherent dehydrogenase and esterase activity, while being non-substrate specific in relation to both reactions. The $\mathrm{ALDH}_{\mathrm{Tt}}$ can catalyse the oxidation of aliphatic, aromatic, and dialdehydes, most notably hexanal and terephthalaldehyde. Biochemical characterisation of the enzyme in terms of substrate scope helps understand possible biological mechanisms, such as the detoxification of certain aldehyde substrates or retinoic acid biosynthesis via association with cytochrome oxidase. Characterisation of the lesser studied prokaryotic ALDH models is important to broaden the understanding of this ever-growing superfamily. Additionally, the thermophilic nature of the $\mathrm{ALDH}_{\mathrm{Tt}}$, working in the range of $20-50{ }^{\circ} \mathrm{C}$, coupled with its broad substrate scope, allows for application of this enzyme in biocatalytic mechanisms. Possible applications relate to the oxidation of aldehydes to synthesise carboxylic acids chemoselectively, or even the hydrolysis of esters for production of desirable alcohols. However, the reduced catalytic rate of the latter needs to be considered.

Supplementary Materials: The following are available online at https://www.mdpi.com/article/ 10.3390/cells10123535/s1, Figure S1: Calibration curve of p-nitrophenol in $10 \mathrm{mM}$ potassium phosphate $\mathrm{pH} 8,0.1 \%$ acetone, Figure S2: Protein sequence alignment of ALDH $\mathrm{Tt}_{\mathrm{Tt}}$ (PDB: 6FJX) and (A) ALDH1A3 (PDB: 5FHZ) and (B) succinate semialdehyde dehydrogenase (SS-ALDH) from E. coli (PDB: 3JZ4), Figure S3: SDS-PAGE of ALDH $_{T t}$ expression and purification fractions omitting the heat treatment step. Lane 1: PageRuler pre-stained protein ladder (ThermoFisher), lane 2: E. coli BL21(DE3) cell lysate expressing $\mathrm{ALDH}_{\mathrm{Tt}}$, lane $3: \mathrm{Ni}$ affinity chromatography $200 \mathrm{mM}$ imidazole elution, lane 4: purified $\mathrm{ALDH}_{\mathrm{Tt}}$, lane 5: Ni affinity chromatography flow through, Figure S4: Michaelis-Menten kinetic plots for $\mathrm{ALDH}_{\mathrm{Tt}}$ with different substrates, (A) hexanal $25^{\circ} \mathrm{C}$, (B) hexanal $50^{\circ} \mathrm{C}$, (C) benzaldehyde $25^{\circ} \mathrm{C}$, (D) benzaldehyde $50^{\circ} \mathrm{C}$, (E) terephthalaldehyde $25^{\circ} \mathrm{C}$, (F) terephthalaldehyde $50{ }^{\circ} \mathrm{C}$, Figure S5: Michaelis-Menten kinetics plot varying [NAD+] for $\mathrm{ALDH}_{\mathrm{Tt}}$ using hexanal at (A) $25^{\circ} \mathrm{C}$ and (B) $50{ }^{\circ} \mathrm{C}$, Figure S6: ALDH $\mathrm{Tt}_{\mathrm{Tt}}$ reaction course over $2 \mathrm{~h}$ using hexanal with NADH production monitored at $340 \mathrm{~nm}$, Figure S7: HPLC chromatogram for the detection of hexanoic acid from $2 \mathrm{~h}$ $\mathrm{ALDH}_{\mathrm{Tt}}$ assay with a retention time of $6.86 \mathrm{~min}$, Figure S8: Absorbance vs. time for esterase activity monitored at $400 \mathrm{~nm}$ at $25^{\circ} \mathrm{C}$ using (A) PNP-acetate and (B) PNP-butyrate, Figure S9: Absorbance vs. time monitored at $400 \mathrm{~nm}$ for esterase activity at $50{ }^{\circ} \mathrm{C}$ using PNP-acetate, Table S1: Aldehyde substrates used for catalysis by $\mathrm{ALDH}_{\mathrm{Tt}}$ highlighting their associated specific activity, Table S2: Esterase substrates catalysed by $\mathrm{ALDH}_{\mathrm{Tt}}$ highlighting their associated specific activity.

Author Contributions: Conceptualization, K.S., E.M. and T.S.; Methodology, K.S., E.M. and T.S.; Formal Analysis, K.S.; Investigation, K.S. and E.D.; Resources, Writing-Original Draft Preparation, K.S., E.M. and T.S.; Writing—Review \& Editing, K.S., E.M. and T.S.; Visualization, K.S.; Supervision, E.M. and T.S.; Funding Acquisition, E.M. and T.S. All authors have read and agreed to the published version of the manuscript.

Funding: This research was funded by European Union's Horizon 2020 Research and Innovation programme, Oyster (Open characterisation and modelling environment to drive innovation in advanced nano-architectured and bio-inspired hard/soft interfaces) under grant agreement No. 760827. Funding is also acknowledged from the Department of Chemical Sciences, University of Limerick and The Higher Education Authority, Ireland. 
Institutional Review Board Statement: Not applicable.

Informed Consent Statement: Not applicable.

Data Availability Statement: Data is contained within the article or Supplementary Materials.

Acknowledgments: We kindly thank Bridget Hogan and the Department of Chemical Sciences, University of Limerick for the donation of HPLC columns.

Conflicts of Interest: The authors declare no conflict of interest.

\section{References}

1. Liu, Z.-J.; Sun, Y.-J.; Rose, J.; Chung, Y.-J.; Hsiao, C.-D.; Chang, W.-R.; Kuo, I.; Perozich, J.; Lindahl, R.; Hempel, J. The first structure of an aldehyde dehydrogenase reveals novel interactions between NAD and the Rossmann fold. Nat. Struct. Biol. 1997, 4, 317-326. [CrossRef] [PubMed]

2. Rodríguez-Zavala, J.S.; Allali-Hassani, A.; Weiner, H. Characterization of E. coli tetrameric aldehyde dehydrogenases with atypical properties compared to other aldehyde dehydrogenases. Protein Sci. 2006, 15, 1387-1396. [CrossRef]

3. Korasick, D.A.; White, T.A.; Chakravarthy, S.; Tanner, J.J. NAD+ promotes assembly of the active tetramer of aldehyde dehydrogenase 7A1. FEBS letters 2018, 592, 3229-3238. [CrossRef]

4. Wyatt, J.W.; Korasick, D.A.; Qureshi, I.A.; Campbell, A.C.; Gates, K.S.; Tanner, J.J. Inhibition, crystal structures, and in-solution oligomeric structure of aldehyde dehydrogenase 9A1. Arch. Biochem. Biophys. 2020, 691, 108477. [CrossRef] [PubMed]

5. Shortall, K.; Djeghader, A.; Magner, E.; Soulimane, T. Insights into Aldehyde Dehydrogenase Enzymes: A Structural Perspective. Front. Mol. Biosci. 2021, 8, 410. [CrossRef] [PubMed]

6. Inagaki, E.; Ohshima, N.; Takahashi, H.; Kuroishi, C.; Yokoyama, S.; Tahirov, T. Crystal structure of Thermus thermophilus $\Delta$ 1-pyrroline-5-carboxylate dehydrogenase. J. Mol. Biol. 2006, 362, 490-501. [CrossRef] [PubMed]

7. Luo, M.; Singh, R.K.; Tanner, J.J. Structural determinants of oligomerization of $\Delta 1$-pyrroline-5-carboxylate dehydrogenase: Identification of a hexamerization hot spot. J. Mol. Biol. 2013, 425, 3106-3120. [CrossRef] [PubMed]

8. Pemberton, T.A.; Srivastava, D.; Sanyal, N.; Henzl, M.T.; Becker, D.F.; Tanner, J.J. Structural studies of yeast $\Delta 1$-pyrroline-5carboxylate dehydrogenase (ALDH4A1): Active site flexibility and oligomeric state. Biochemistry 2014, 53, 1350-1359. [CrossRef]

9. Feldman, R.I.; Weiner, H. Horse liver aldehyde dehydrogenase II. Kinetics and mechanistic implications of the dehydrogenase and esterase activity. J. Biol. Chem. 1972, 247, 267-272. [CrossRef]

10. MAcGIBBON, A.K.; Haylock, S.J.; Buckley, P.D.; Blackwell, L. Kinetic studies on the esterase activity of cytoplasmic sheep liver aldehyde dehydrogenase. Biochem. J. 1978, 171, 533-538. [CrossRef]

11. Sydow, K.; Daiber, A.; Oelze, M.; Chen, Z.; August, M.; Wendt, M.; Ullrich, V.; Mülsch, A.; Schulz, E.; Keaney, J.F. Central role of mitochondrial aldehyde dehydrogenase and reactive oxygen species in nitroglycerin tolerance and cross-tolerance. J. Clin. Investig. 2004, 113, 482-489. [CrossRef] [PubMed]

12. Duncan, R. Aldehyde dehydrogenase. An enzyme with two distinct catalytic activities at a single type of active site. Biochem. J. 1985, 230, 261-267. [CrossRef]

13. Koppaka, V.; Thompson, D.C.; Chen, Y.; Ellermann, M.; Nicolaou, K.C.; Juvonen, R.O.; Petersen, D.; Deitrich, R.A.; Hurley, T.D.; Vasiliou, V. Aldehyde dehydrogenase inhibitors: A comprehensive review of the pharmacology, mechanism of action, substrate specificity, and clinical application. Pharmacol. Rev. 2012, 64, 520-539. [CrossRef]

14. Daiber, A.; Oelze, M.; Coldewey, M.; Bachschmid, M.; Wenzel, P.; Sydow, K.; Wendt, M.; Kleschyov, A.L.; Stalleicken, D.; Ullrich, V. Oxidative stress and mitochondrial aldehyde dehydrogenase activity: A comparison of pentaerythritol tetranitrate with other organic nitrates. Mol. Pharmacol. 2004, 66, 1372-1382. [CrossRef]

15. Mann, C.J.; Weiner, H. Differences in the roles of conserved glutamic acid residues in the active site of human class 3 and class 2 aldehyde dehydrogenases. Protein Sci. 1999, 8, 1922-1929. [CrossRef] [PubMed]

16. Hoshino, T.; Yamabe, E.; Hawari, M.A.; Tamura, M.; Kanamaru, S.; Yoshida, K.; Koesoema, A.A.; Matsuda, T. Oxidation of aromatic and aliphatic aldehydes to carboxylic acids by Geotrichum candidum aldehyde dehydrogenase. Tetrahedron 2020, 76, 131387. [CrossRef]

17. Ambroziak, W.; Pietruszko, R. Human aldehyde dehydrogenase. Activity with aldehyde metabolites of monoamines, diamines, and polyamines. J. Biol. Chem. 1991, 266, 13011-13018. [CrossRef]

18. Kitamura, T.; Naganuma, T.; Abe, K.; Nakahara, K.; Ohno, Y.; Kihara, A. Substrate specificity, plasma membrane localization, and lipid modification of the aldehyde dehydrogenase ALDH3B1. Biochim. Et Biophys. Acta (BBA)-Mol. Cell Biol. Lipids 2013, 1831, 1395-1401. [CrossRef] [PubMed]

19. Ouyang, Y.; Li, Q.; Kuang, X.; Wang, H.; Wu, J.; Ayepa, E.; Chen, H.; Abrha, G.T.; Zhang, Z.; Li, X. YMR152W from Saccharomyces cerevisiae encoding a novel aldehyde reductase for detoxification of aldehydes derived from lignocellulosic biomass. J. Biosci. Bioeng. 2020, 131, 39-46. [CrossRef] [PubMed]

20. Choudhary, S.; Xiao, T.; Vergara, L.A.; Srivastava, S.; Nees, D.; Piatigorsky, J.; Ansari, N.H. Role of aldehyde dehydrogenase isozymes in the defense of rat lens and human lens epithelial cells against oxidative stress. Investig. Ophthalmol. Vis. Sci. 2005, 46, 259-267. [CrossRef] [PubMed] 
21. Marchitti, S.A.; Deitrich, R.A.; Vasiliou, V. Neurotoxicity and metabolism of the catecholamine-derived 3, 4-dihydroxyphenylacetal dehyde and 3, 4-dihydroxyphenylglycolaldehyde: The role of aldehyde dehydrogenase. Pharmacol. Rev. 2007, 59, 125-150. [CrossRef] [PubMed]

22. Pequerul, R.; Vera, J.; Giménez-Dejoz, J.; Crespo, I.; Coines, J.; Porté, S.; Rovira, C.; Parés, X.; Farrés, J. Structural and kinetic features of aldehyde dehydrogenase 1A (ALDH1A) subfamily members, cancer stem cell markers active in retinoic acid biosynthesis. Arch. Biochem. Biophys. 2020, 681, 108256. [CrossRef] [PubMed]

23. Yoshida, A.; Hsu, L.C.; Davé, V. Retinal oxidation activity and biological role of human cytosolic aldehyde dehydrogenase. Enzyme 1992, 46, 239-244. [CrossRef]

24. Marchitti, S.A.; Chen, Y.; Thompson, D.C.; Vasiliou, V. Ultraviolet radiation: Cellular antioxidant response and the role of ocular aldehyde dehydrogenase enzymes. Eye Contact Lens 2011, 37, 206. [CrossRef]

25. Voulgaridou, G.-P.; Tsochantaridis, I.; Tolkas, C.; Franco, R.; Giatromanolaki, A.; Panayiotidis, M.I.; Pappa, A. Aldehyde dehydrogenase 3A1 confers oxidative stress resistance accompanied by altered DNA damage response in human corneal epithelial cells. Free. Radic. Biol. Med. 2020, 150, 66-74. [CrossRef] [PubMed]

26. Piatigorsky, J. Multifunctional lens crystallins and corneal enzymes: More than meets the eye. Ann. N. Y. Acad. Sci. 1998, 842, 7-15. [CrossRef] [PubMed]

27. Moreb, J.S. Aldehyde dehydrogenase as a marker for stem cells. Curr. Stem Cell Res. Ther. 2008, 3, 237-246. [CrossRef] [PubMed]

28. Vassalli, G. Aldehyde dehydrogenases: Not just markers, but functional regulators of stem cells. Stem Cells Int. 2019, 2019, 3904645-3904660. [CrossRef] [PubMed]

29. Liu, L.-K.; Tanner, J.J. Crystal structure of aldehyde dehydrogenase 16 reveals trans-hierarchical structural similarity and a new dimer. J. Mol. Biol. 2019, 431, 524-541. [CrossRef]

30. Hayes, K.; Noor, M.; Djeghader, A.; Armshaw, P.; Pembroke, T.; Tofail, S.; Soulimane, T. The quaternary structure of Thermus thermophilus aldehyde dehydrogenase is stabilized by an evolutionary distinct C-terminal arm extension. Sci. Rep. 2018, 8, 1-14.

31. Riveros-Rosas, H.; Julián-Sánchez, A.; Moreno-Hagelsieb, G.; Muñoz-Clares, R.A. Aldehyde dehydrogenase diversity in bacteria of the Pseudomonas genus. Chemico-Biol. Interact. 2019, 304, 83-87. [CrossRef]

32. Miah, R.; Nina, S.; Murate, T.; Kataoka, N.; Matsutani, M.; Matsushita, K.; Yakushi, T. Major aldehyde dehydrogenase AldFGH of Gluconacetobacter diazotrophicus is independent of pyrroloquinoline quinone but dependent on molybdopterin for acetic acid fermentation. Appl. Microbiol. Biotechnol. 2021, 105, 2341-2350. [CrossRef] [PubMed]

33. Hempel, J.; Kaiser, R.; Jörnvall, H. Mitochondrial aldehyde dehydrogenase from human liver: Primary structure, differences in relation to the cytosolic enzyme, and functional correlations. Eur. J. Biochem. 1985, 153, 13-28. [CrossRef]

34. Boyd, L.A.; Adam, L.; Pelcher, L.E.; McHughen, A.; Hirji, R.; Selvaraj, G. Characterization of an Escherichia coli gene encoding betaine aldehyde dehydrogenase (BADH): Structural similarity to mammalian ALDHs and a plant BADH. Gene 1991, 103, 45-52. [CrossRef]

35. Kato, T.; Miyanaga, A.; Kanaya, S.; Morikawa, M. Gene cloning and characterization of an aldehyde dehydrogenase from long-chain alkane-degrading Geobacillus thermoleovorans B23. Extremophiles 2010, 14, 33-39. [CrossRef] [PubMed]

36. Miles, J.A.; Machattou, P.; Nevin-Jones, D.; Webb, M.E.; Millard, A.; Scanlan, D.J.; Taylor, P.C. Identification of a cyanobacterial aldehyde dehydrogenase that produces retinoic acid in vitro. Biochem. Biophys. Res. Commun. 2019, 510, 27-34. [CrossRef] [PubMed]

37. Hong, S.-H.; Ngo, H.-P.-T.; Nam, H.-K.; Kim, K.-R.; Kang, L.-W.; Oh, D.-K. Alternative biotransformation of retinal to retinoic acid or retinol by an aldehyde dehydrogenase from Bacillus cereus. Appl. Environ. Microbiol. 2016, 82, 3940-3946. [CrossRef] [PubMed]

38. Coitinho, J.B.; Pereira, M.S.; Costa, D.b.M.; Guimaraes, S.L.; Araujo, S.S.; Hengge, A.C.; Brandao, T.A.; Nagem, R.A. Structural and kinetic properties of the aldehyde dehydrogenase NahF, a broad substrate specificity enzyme for aldehyde oxidation. Biochemistry 2016, 55, 5453-5463. [CrossRef]

39. Li, X.; Li, Y.; Wei, D.; Li, P.; Wang, L.; Feng, L. Characterization of a broad-range aldehyde dehydrogenase involved in alkane degradation in Geobacillus thermodenitrificans NG80-2. Microbiol. Res. 2010, 165, 706-712. [CrossRef]

40. Knaus, T.; Tseliou, V.; Humphreys, L.D.; Scrutton, N.S.; Mutti, F.G. A biocatalytic method for the chemoselective aerobic oxidation of aldehydes to carboxylic acids. Green Chem. 2018, 20, 3931-3943. [CrossRef]

41. Wu, S.; Zhou, Y.; Seet, D.; Li, Z. Regio-and Stereoselective Oxidation of Styrene Derivatives to Arylalkanoic Acids via One-Pot Cascade Biotransformations. Adv. Synth. Catal. 2017, 359, 2132-2141. [CrossRef]

42. Winkler, T.; Gröger, H.; Hummel, W. Enantioselective Rearrangement Coupled with Water Addition: Direct Synthesis of Enantiomerically Pure Saturated Carboxylic Acids from $\alpha, \beta$-Unsaturated Aldehydes. ChemCatChem 2014, 6, 961-964. [CrossRef]

43. Atalah, J.; Cáceres-Moreno, P.; Espina, G.; Blamey, J.M. Thermophiles and the applications of their enzymes as new biocatalysts. Bioresour. Technol. 2019, 280, 478-488. [CrossRef] [PubMed]

44. Lyons, J.A.; Aragão, D.; Slattery, O.; Pisliakov, A.V.; Soulimane, T.; Caffrey, M. Structural insights into electron transfer in caa 3-type cytochrome oxidase. Nature 2012, 487, 514-518. [CrossRef] [PubMed]

45. Zimmerling, J.; Oelschlägel, M.; Großmann, C.; Voitel, M.; Schlömann, M.; Tischler, D. Biochemical Characterization of Phenylacetaldehyde Dehydrogenases from Styrene-degrading Soil Bacteria. Appl. Biochem. Biotechnol. 2021, 193, 650-667. [CrossRef]

46. Vasiliou, V.; Bairoch, A.; Tipton, K.F.; Nebert, D.W. Eukaryotic aldehyde dehydrogenase (ALDH) genes: Human polymorphisms, and recommended nomenclature based on divergent evolution and chromosomal mapping. Pharm. Genom. 1999, 9, $421-434$. 
47. Moretti, A.; Li, J.; Donini, S.; Sobol, R.W.; Rizzi, M.; Garavaglia, S. Crystal structure of human aldehyde dehydrogenase 1A3 complexed with NAD+ and retinoic acid. Sci. Rep. 2016, 6, 1-12. [CrossRef] [PubMed]

48. Sobreira, T.J.; Marlétaz, F.; Simões-Costa, M.; Schechtman, D.; Pereira, A.C.; Brunet, F.; Sweeney, S.; Pani, A.; Aronowicz, J.; Lowe, C.J. Structural shifts of aldehyde dehydrogenase enzymes were instrumental for the early evolution of retinoid-dependent axial patterning in metazoans. Proc. Natl. Acad. Sci. USA 2011, 108, 226-231. [CrossRef] [PubMed]

49. Klyosov, A.A. Kinetics and specificity of human liver aldehyde dehydrogenases toward aliphatic, aromatic, and fused polycyclic aldehydes. Biochemistry 1996, 35, 4457-4467. [CrossRef] [PubMed]

50. Moore, S.A.; Baker, H.M.; Blythe, T.J.; Kitson, K.E.; Kitson, T.M.; Baker, E.N. Sheep liver cytosolic aldehyde dehydrogenase: The structure reveals the basis for the retinal specificity of class 1 aldehyde dehydrogenases. Structure 1998, 6, 1541-1551. [CrossRef]

51. Lorentzen, E.; Hensel, R.; Knura, T.; Ahmed, H.; Pohl, E. Structural basis of allosteric regulation and substrate specificity of the non-phosphorylating glyceraldehyde 3-phosphate dehydrogenase from Thermoproteus tenax. J. Mol. Biol. 2004, 341, 815-828. [CrossRef]

52. Liu, T.; Hao, L.; Wang, R.; Liu, B. Molecular characterization of a thermostable aldehyde dehydrogenase (ALDH) from the hyperthermophilic archaeon Sulfolobus tokodaii strain 7. Extremophiles 2013, 17, 181-190. [CrossRef]

53. Ettema, T.J.; Ahmed, H.; Geerling, A.C.; van der Oost, J.; Siebers, B. The non-phosphorylating glyceraldehyde-3-phosphate dehydrogenase (GAPN) of Sulfolobus solfataricus: A key-enzyme of the semi-phosphorylative branch of the Entner-Doudoroff pathway. Extremophiles 2008, 12, 75-88. [CrossRef] [PubMed]

54. Millard, A.; Scanlan, D.J.; Gallagher, C.; Marsh, A.; Taylor, P.C. Unexpected evolutionary proximity of eukaryotic and cyanobacterial enzymes responsible for biosynthesis of retinoic acid and its oxidation. Mol. BioSystems 2014, 10, 380-383. [CrossRef] [PubMed]

55. Brash, A.R.; Niraula, N.P.; Boeglin, W.E.; Mashhadi, Z. An ancient relative of cyclooxygenase in cyanobacteria is a linoleate 10S-dioxygenase that works in tandem with a catalase-related protein with specific 10S-hydroperoxide lyase activity. J. Biol. Chem. 2014, 289, 13101-13111. [CrossRef] [PubMed]

56. Ponting, C.; Aravind, L.; Schultz, J.; Bork, P.; Koonin, E. Eukaryotic signalling domain homologues in archaea and bacteria. Ancient ancestry and horizontal gene transfer. J. Mol. Biol. 1999, 289, 729-745. [CrossRef] [PubMed]

57. Rawlings, N.D. Bacterial calpains and the evolution of the calpain (C2) family of peptidases. Biol. Direct 2015, 10, 1-12. [CrossRef]

58. Sun, F.; Zhang, X.-Z.; Myung, S.; Zhang, Y.-H.P. Thermophilic Thermotoga maritima ribose-5-phosphate isomerase RpiB: Optimized heat treatment purification and basic characterization. Protein Expr. Purif. 2012, 82, 302-307. [CrossRef]

59. Xu, J.; Luo, H.; López, C.; Xiao, J.; Chang, Y. Novel immobilization process of a thermophilic catalase: Efficient purification by heat treatment and subsequent immobilization at high temperature. Bioprocess Biosyst. Eng. 2015, 38, 1983-1991. [CrossRef]

60. Patchett, M.; Neal, T.; Schofield, L.; Strange, R.; Daniel, R.; Morgan, H. Heat treatment purification of thermostable cellulase and hemicellulase enzymes expressed in E. coli. Enzym. Microb. Technol. 1989, 11, 113-115. [CrossRef]

61. Pennacchio, A.; Pucci, B.; Secundo, F.; La Cara, F.; Rossi, M.; Raia, C.A. Purification and characterization of a novel recombinant highly enantioselective short-chain NAD (H)-dependent alcohol dehydrogenase from Thermus thermophilus. Appl. Environ. Microbiol. 2008, 74, 3949-3958. [CrossRef] [PubMed]

62. Inagaki, E.; Takahashi, H.; Kuroishi, C.; Tahirov, T.H. Crystallization and avoiding the problem of hemihedral twinning in crystals of $\Delta 1$-pyrroline-5-carboxylate dehydrogenase from Thermus thermophilus. Acta Crystallogr. Sect. F Struct. Biol. Cryst. Commun. 2005, 61, 609-611. [CrossRef] [PubMed]

63. Miyazaki, K.; Yaoi, T.; Oshima, T. Expression, purification, and substrate specificity of isocitrate dehydrogenase from Thermus thermophilus HB8. Eur. J. Biochem. 1994, 221, 899-903. [CrossRef]

64. Ng, M.Y.; Tan, W.S.; Abdullah, N.; Ling, T.C.; Tey, B.T. Heat treatment of unclarified Escherichia coli homogenate improved the recovery efficiency of recombinant hepatitis B core antigen. J. Virol. Methods 2006, 137, 134-139. [CrossRef]

65. Kalthoff, C. A novel strategy for the purification of recombinantly expressed unstructured protein domains. J. Chromatogr. B 2003, 786, 247-254. [CrossRef]

66. Jonasson, P.; Nygren, P.-Å.; Jörnvall, H.; Johansson, B.-L.; Wahren, J.; Uhlén, M.; Ståhl, S. Integrated bioprocess for production of human proinsulin C-peptide via heat release of an intracellular heptameric fusion protein. J. Biotechnol. 2000, 76, 215-226. [CrossRef]

67. Oshima, T.; Imahori, K. Description of Thermus thermophilus (Yoshida and Oshima) comb. nov., a nonsporulating thermophilic bacterium from a Japanese thermal spa. Int. J. Syst. Evol. Microbiol. 1974, 24, 102-112. [CrossRef]

68. Ohtani, N.; Tomita, M.; Itaya, M. An extreme thermophile, Thermus thermophilus, is a polyploid bacterium. J. Bacteriol. 2010, 192, 5499-5505. [CrossRef]

69. Miyamoto, T.; Moriya, T.; Homma, H.; Oshima, T. Enzymatic properties and physiological function of glutamate racemase from Thermus thermophilus. Biochim. Biophys. Acta (BBA)-Proteins Proteom. 2020, 1868, 140461. [CrossRef] [PubMed]

70. Kozono, I.; Hibi, M.; Takeuchi, M.; Ogawa, J. Purification and characterization of molybdenum-containing aldehyde dehydrogenase that oxidizes benzyl maltol derivative from Pseudomonas nitroreducens SB32154. Biosci. Biotechnol. Biochem. 2020, 84, 2390-2400. [CrossRef] [PubMed]

71. Singh, P.; Kaufholdt, D.; Awadalah, M.; Hänsch, R.; Beerhues, L.; Gaid, M. Cytosolic aromatic aldehyde dehydrogenase provides benzoic acid for xanthone biosynthesis in Hypericum. Plant Physiol. Biochem. 2021, 160, 82-93. [CrossRef] [PubMed] 
72. Pang, J.; Zheng, M.; Sun, R.; Wang, A.; Wang, X.; Zhang, T. Synthesis of ethylene glycol and terephthalic acid from biomass for producing PET. Green Chem. 2016, 18, 342-359. [CrossRef]

73. Tomas, R.R.A.; Bordado, J.O.C.; Gomes, J.O.F. p-Xylene oxidation to terephthalic acid: A literature review oriented toward process optimization and development. Chem. Rev. 2013, 113, 7421-7469. [CrossRef]

74. Ho, K.K.; Hurley, T.D.; Weiner, H. Selective alteration of the rate-limiting step in cytosolic aldehyde dehydrogenase through random mutagenesis. Biochemistry 2006, 45, 9445-9453. [CrossRef] [PubMed]

75. Sidhu, R.S.; Blair, A.H. Human liver aldehyde dehydrogenase. Esterase activity. J. Biol. Chem. 1975, 250, 7894-7898. [CrossRef]

76. Ferrández, A.; Prieto, M.a.A.; Garcia, J.L.; Diaz, E. Molecular characterization of PadA, a phenylacetaldehyde dehydrogenase from Escherichia coli. FEBS Lett. 1997, 406, 23-27. [CrossRef]

77. Blackwell, L.F.; Bennett, A.F.; Buckley, P.D. Relationship between the mechanisms of the esterase and dehydrogenase activities of the cytoplasmic aldehyde dehydrogenase from sheep liver. An alternative view. Biochemistry 1983, 22, 3784-3791. [CrossRef]

78. Lindahl, R.; Evces, S. Rat liver aldehyde dehydrogenase. I. Isolation and characterization of four high Km normal liver isozymes. J. Biol. Chem. 1984, 259, 11986-11990. [CrossRef]

79. Rodríguez-Zavala, J.S.; Ortiz-Cruz, M.A.; Moreno-Sanchez, R. Characterization of an aldehyde dehydrogenase from Euglena gracilis. J. Eukaryot. Microbiol. 2006, 53, 36-42. [CrossRef] [PubMed] 